2. To: (Receiving Organization)

Distribution
3. From: (Originating Organization)

Engineering Development \& Disposal Systems

6. Cog. Engr.:

K. L. Hampsten
5. Proj./Prog./Dept./Div.: SSB/ED\&DS/TWRS

8. Originator Remarks:

Initial issue for public release

RECEIVED

OCT 039984

Page 1 of 1. EDT 605426

7. Purchase Order No.:

$N / A$

9. Equip./Component No.:

$N / A$

10. System/Bldg./Facility:

$\mathrm{N} / \mathrm{A}$

081

11. Receiver Remarks:

12. Major Assm. Dwg. No.:

$N / A$

13. Permit/Permit Application No.: $N / A$

14. Required Response Date: $N / A$

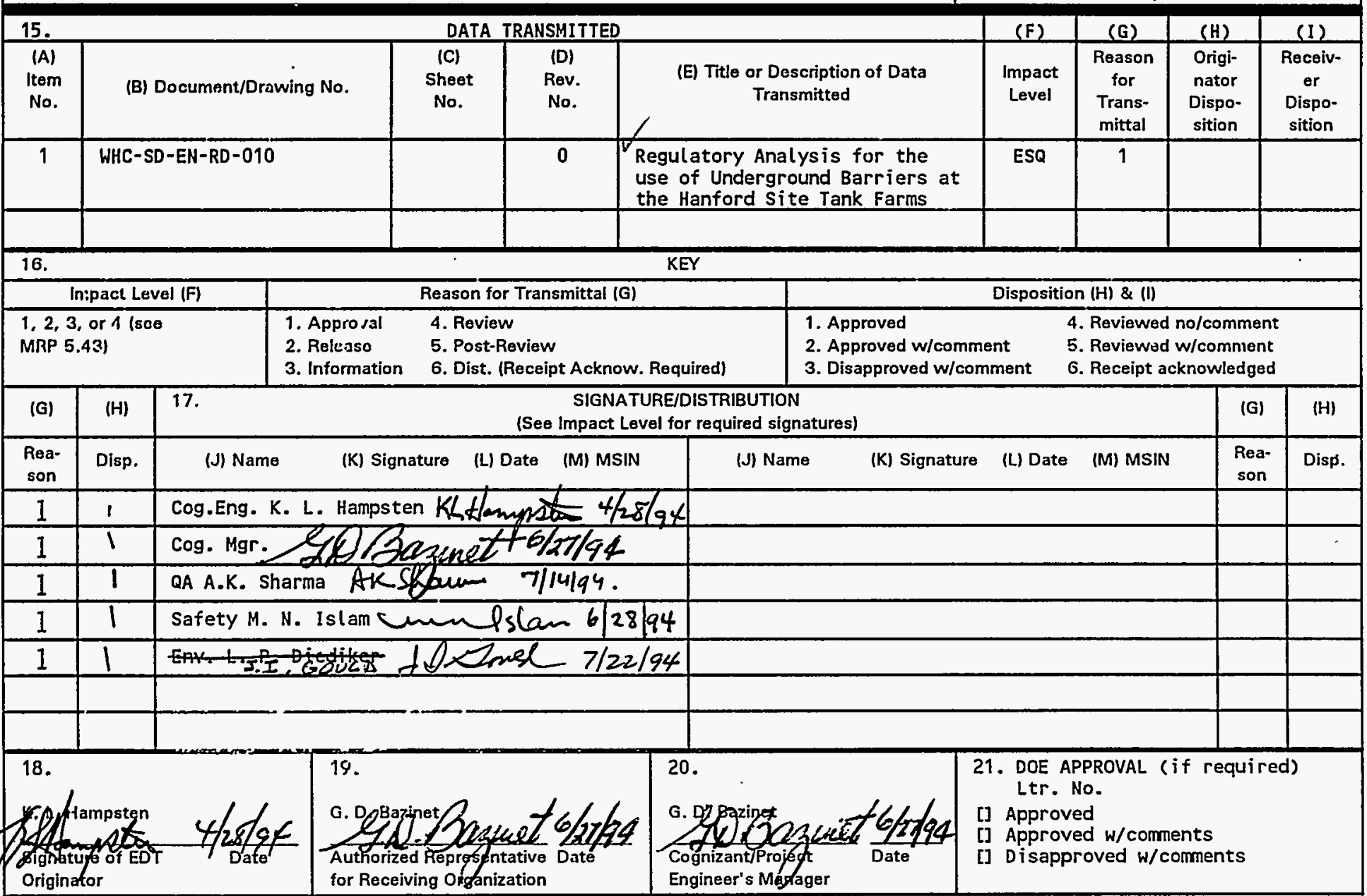




\section{DISCLAIMER}

Portions of this document may be illegible in electronic image products. Images are produced from the best available original document. 


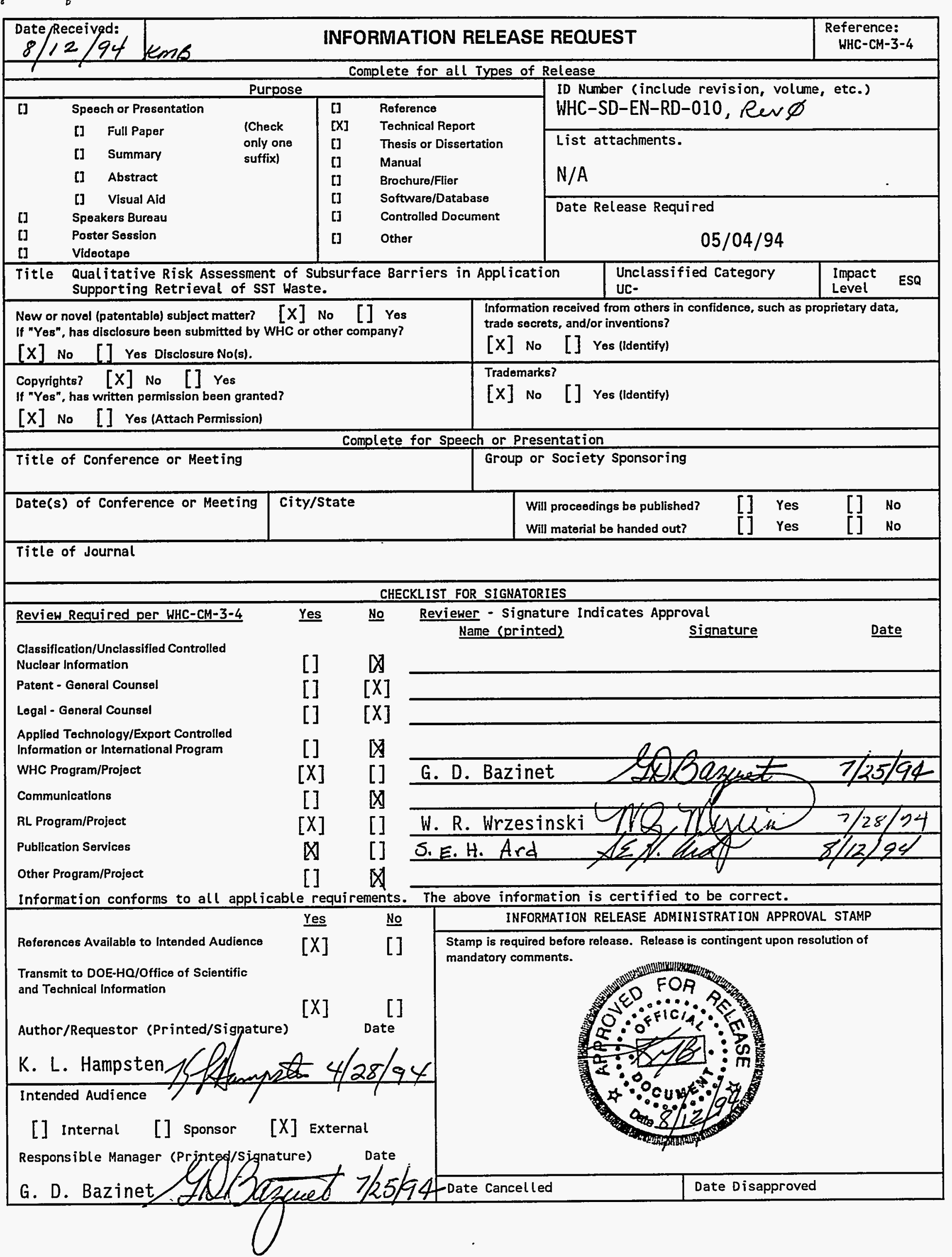


2. Title

Regulatory Analysis for the use of Underground Barriers at the Hanford Site Tank Farms

\section{Key Words}

Barriers, Tank Farms, Subsurface Barriers, Regulatory Assessment, Permitting Strategy, Single-Shel1 Tank Farms, Circulating Air Barrier, Injected Materials Barrier, Frozen Soit Barrier.....

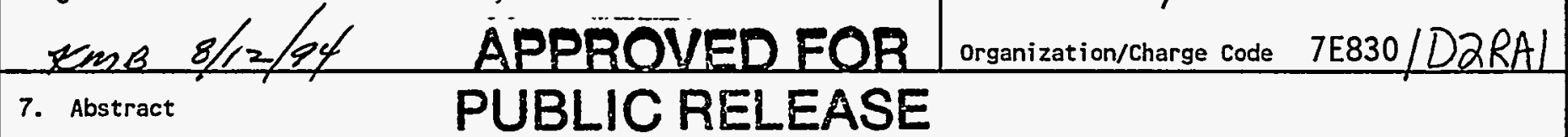

This document evaluates the regulatory requirements associated with construction of an underground barrier at the Hanford Site Tank Farms. This document also provides a permitting strategy which identifies the necessary environmental permits and notifications associated with construction of an underground barrier system.

8. PURPOSE AND USE OF DOCUMENT - This document was prepared for the with in tha U.S. Department of Energy and its contractors. It is to be used ont to perform, direct, or integrate work under U.S. Department of Energy contracts. This document is not approved for public release unt theviewed.

PATENT STATUS - This document cope since it is transmitted in advance of patent clearance, is made arailable in confidence solely for use in performance of work under contracts with the U.S. Department of Energy. This document is not te be published nor its contents otherwise disseminated or used for purposes other than specified atorve before patent approval for such release on use has been secured, upon request, from the Patent Counsel, U.S. Departifent

$$
\sqrt{1}
$$

DISCLAIMER - This report was prepared as an account of work sponsored by an agency of the United States Government. Neither the United States Government nor any agency thereof, nor any of their employees, nor any of their contractors, subcontractors or their employees, makes any warranty, express or implied, or assumes any legal liability or responsibility for the accuracy, completeness, or any third party's use or the results of such use of any information, apparatus, product, or process disclosed, or represents that its use would not infringe privately owned rights. Reference herein to any specific commercial product, process, or service by trade name, trademark, manufacturer, or otherwise, does not necessarily constitute or imply its endorsement, recomendation, or favoring by the United States Government or any agency thereof or its contractors or subcontractors. The views and opinions of authors expressed herein do not necessarily state or reflect those of the United States Government or any agency thereof.

9. Impact Level ESQ
10.

RELEASE STAMP
OFFICIAL RELEASE BY WHC

\section{DATE}

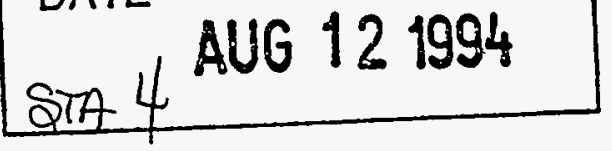




\title{
Regulatory Analysis for the Use of Underground Barriers at the Hanford Site
}

\author{
E. H. Smith
}

Date Published

May 1994

Prepared for the.U.S. Department of Energy

Office of Environmental Restoration

and Waste Management

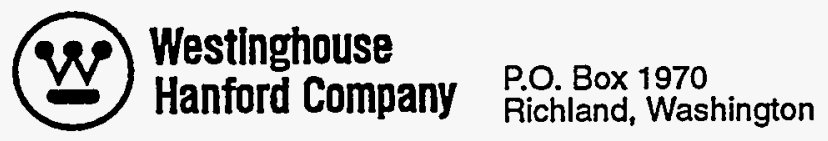

Hanford Operations and Engineering Contractor for the

U.S. Department of Energy under Contract DE-AC06-87RL 10930

Approved for Public Release 


\section{ABSTRACT}

Sixty-seven of the single-shell tanks at the Hanford Site, Richland, Washington, are assumed to have leaked in the past. Some of the waste retrieval options being considered, such as past-practice sluicing (a process that uses hot water to dislodge waste for subsequent removal by pumping), have the potential for increasing releases of dangerous waste from these tanks.

Underground barrier systems are being evaluated as a method to mitigate releases of tank waste to the soil and groundwater that may occur during retrieval activities.

The following underground barrier system options are among those being evaluated to determine whether their construction at the Single-Shell Tank Farms is viable.

- A desiccant barrier would be created by circulating air through the subsurface soil to lower and then maintain the water saturation below the levels required for liquids to flow. Air and water vapors are collected at the surface, dehydrated to remove the water vapor, and then filtered to remove any contaminants or particulate matter. The dry air is then recirculated through the soil column.

- An injected materials barrier would be created by injecting materials such as grout or silica into the subsurface soils to form a barrier around and under a given tank or tank farm.

- A cryogenic barrier would be created by freezing subsurface soils in the vicinity of a tank or tank farm. This type of barrier may use a circulating brine solution or nitrogen to freeze the subsurface soil.

Sections 2.0 through 7.0 of this document provide an analysis of the major regulatory requirements that may impact full scale construction and operation of an underground barrier system and a discussion of factors that should be considered throughout the barrier selection 
process, irrespective of the type of underground barrier system being considered. However, specific barrier systems will be identified when a given regulation will have significant impact on a particular type of barrier technology. Appendix A provides a matrix of requirements applicable to construction and operation of an underground barrier system, including regulations that are not discussed in detail in Sections 2.0 thorough 7.0. Any requirement identified in the Appendix $A$ matrix as being applicable is clarified with a note following the matrix. 


\section{CONTENTS}

1.0 BACKGROUND . . . . . . . . . . . . . . . . . . . . . . 1-1

1.1 REGULATORY STATUS OF THE SSTS $\ldots \ldots \ldots \ldots \ldots \ldots \ldots$

2.0 REGULATORY REQUIREMENTS . . . . . . . . . . . . . . 2-1

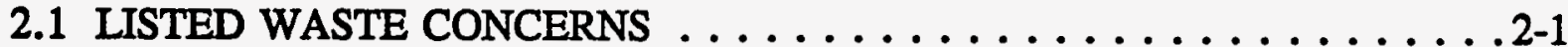

2.2 UNDERGROUND BARRIER SYSTEM REQUIREMENTS $\ldots \ldots \ldots \ldots . . .2-2$

2.3 EXPANSION OF EXISTING UNITS . . . . . . . . . . . . 2-3

2.4 USE OF REGULATED BARRIER MATERIALS $\ldots \ldots \ldots \ldots \ldots \ldots .2-5$

2.5 MANAGEMENT OF SECONDARY WASTEWATER $\ldots \ldots \ldots \ldots \ldots$. . . . .

2.5.1 Manage Contaminated Wastewater

in New Storage Tanks . . . . . . . . . . . . . . . . . . . . 2-7

2.5.2 Manage Wastewater in Existing Tanks . . . . . . . . . . . 2-8

2.5.3 Manage Wastewater in the Liquid

Effluent Retention Facility . . . . . . . . . . . . . . . . . 2-9

2.5.4 Manage.Wastewater in the Purgewater Modutanks . . . . . . 2-10

2.6 DELISTING ISSUES . . . . . . . . . . . . . . . . . . . 2-11

2.7 LAND DISPOSAL RESTRICTIONS . . . . . . . . . . . 2-11

2.7.1 Federal LDR Considerations . . . . . . . . . . . . 2-12

2.7.2 Impermissible Dilution . . . . . . . . . . . . 2-12

2.7.3 State Land Disposal Restriction

Considerations . . . . . . . . . . . . . . . . . . . 2-13

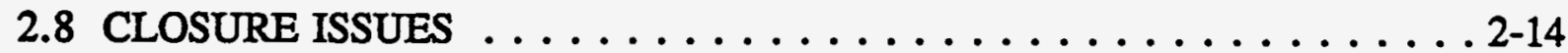

3.0 WASTEWATER DISCHARGES $\ldots \ldots \ldots \ldots \ldots \ldots \ldots \ldots$. . . . . . .

4.0 AIR EMISSIONS $\ldots \ldots \ldots \ldots \ldots \ldots \ldots \ldots \ldots . \ldots \ldots$. . . . . . . . . . . .

4.1 NATIONAL EMISSION STANDARDS FOR HAZARDOUS

AIR POLLUTANTS, 40 CFR 61 , SUBPART H . . . . . . . . . . . 4-1

4.2 RADIATION PROTECTION--AIR EMISSIONS, WAC 246-247 . . . . . . 4-2

4.3 CONTROLS FOR NEW SOURCES OF TOXIC

AIR POLLUTANTS, WAC $173-460 \ldots \ldots \ldots \ldots$. . . . . . . . . . 4-2

5.0 NATIONAL ENVIRONMENTAL POLICY ACT . . . . . . . . . . . 5-1

5.1 CATEGORICAL EXCLUSION AND ACTION DESCRIPTION

MEMORANDUM . . . . . . . . . . . . . . . . 5-1

5.2 ENVIRONMENTAL ASSESSMENT . . . . . . . . . . . 5-1

5.3 ENVIRONMENTAL IMPACT STATEMENT $\ldots \ldots \ldots \ldots \ldots \ldots . . .5-2$

5.4 REQUIRED LEVEL OF NEPA DOCUMENTATION . . . . . . . . . . 5-2

6.0 STATE ENVIRONMENTAL POLICY ACT $\ldots \ldots \ldots \ldots \ldots \ldots \ldots$. . . . . . .

6.1 COVERED ACTIONS . . . . . . . . . . . . . . 6-1

6.2 THRESHOLD DETERMINATIONS . . . . . . . . . . 6-1 
6.3 DETERMINATION OF NON-SIGNIFICANCE . . . . . . . . . . . . . . 6-2

6.4 REQUIRED LEVEL OF SEPA DOCUMENTATION $\ldots \ldots \ldots \ldots \ldots \ldots . . \ldots 6-2$

7.0 REGULATORY REQUIREMENTS SUMMARY . . . . . . . . . . . . . 7-1

7.1 NATIONAL ENVIRONMENTAL POLICY ACT DOCUMENTATION . . . . 7-1

7.2 AIR EMISSION PERMITS AND NOTIFICATIONS . . . . . . . . . . 7-1

7.3 MISCELLANEOUS PERMITS AND APPROVALS $\ldots \ldots \ldots \ldots \ldots \ldots . \ldots .1$

7.4 STATE ENVIRONMENTAL POLICY ACT . . . . . . . . . . . 7-2

7.5 WASTEWATER DISCHARGES $\ldots \ldots \ldots \ldots \ldots \ldots \ldots \ldots \ldots . \ldots \ldots . . \ldots \ldots$

7.6 DANGEROUS WASTE MANAGEMENT $\ldots \ldots \ldots \ldots \ldots \ldots \ldots \ldots$

8.0 REFERENCES . . . . . . . . . . . . . . . . . . . .8-1

8.1 DOCUMENTS . . . . . . . . . . . . . . . . . 8-1

8.2 CODE OF FEDERAL REGULATIONS

AND FEDERAL REGISTER $\ldots \ldots \ldots \ldots \ldots \ldots \ldots \ldots \ldots . \ldots . \ldots . . \ldots$.

8.3 FEDERAL AND STATE ACTS $\ldots \ldots \ldots \ldots \ldots \ldots \ldots \ldots . . \ldots . . \ldots .2$

8.4 WASHINGTON ADMINISTRATIVE CODE $\ldots \ldots \ldots \ldots \ldots \ldots . . . . . . .2$

APPENDIX

REGULATORY REQUIREMENTS $\ldots \ldots \ldots \ldots \ldots \ldots \ldots \ldots$ 


\section{LIST OF TERMS}

\begin{tabular}{|c|c|}
\hline $\mathrm{ADM}$ & Action Description Memorandum \\
\hline ASIL & Acceptable Source Impact Levels \\
\hline BARCT & Best Available Radionuclide Control Technology \\
\hline CAA & Clean Air Act \\
\hline $\mathrm{CAB}$ & Circulating Air Barrier \\
\hline CEDE & Committed Effective Dose Equivalent \\
\hline CERCLA & $\begin{array}{l}\text { Comprehensive Environmental, Response, Compensation, And } \\
\text { Liability Act Of } 1980\end{array}$ \\
\hline CFR & Code Of Federal Regulations \\
\hline CX & Categorical Exclusion \\
\hline DNS & Determination Of Non-Significance \\
\hline DOE & U.S. Department Of Energy \\
\hline DOE-HQ & U.S. Department Of Energy - Headquarters \\
\hline DOH & State Of Washington Department Of Health \\
\hline DST & Double-Shell Tank \\
\hline EA & Environmental Assessment \\
\hline Ecology & State Of Washington Department Of Ecology \\
\hline EIS & Environmental Impact Statement \\
\hline EPA & U.S. Environmental Protection Agency \\
\hline ETF & Effluent Treatment Facility \\
\hline FONSI & Finding Of Non-Significant Impact \\
\hline $\mathrm{HH}$ & Halogenated Hydrocarbons \\
\hline HLW & High-Level Waste \\
\hline IARC & International Agency For Research On Cancer \\
\hline LERF & Liquid Effluent Retention Facility \\
\hline LDR & Land Disposal Restrictions \\
\hline MEI & Maximally Exposed Individual \\
\hline Modutanks & 600 Area Purge Water Storage And Treatment Facility \\
\hline MTCA & Model Toxics Control Act \\
\hline NEPA & National Environmental Policy Act Of 1969 \\
\hline NESHAP & National Emission Standard for Hazardous Air Pollutant \\
\hline NIOSH & National Institute For Occupational Safety And Health \\
\hline NOC & Notice Of Construction \\
\hline NOI & Notice Of Intent \\
\hline PAH & Polycyclic Aromatic Hydrocarbons \\
\hline RCRA & Resource Conservation And Recovery Act Of 1976 \\
\hline RL & U.S. Department Of Energy, Richland Operations Office \\
\hline ROD & Record Of Decision \\
\hline SEPA & State Environmental Policy Act Of 1971 \\
\hline SST & Single-Shell Tank \\
\hline SWDP & State Waste Discharge Permit \\
\hline TAP & Toxic Air Pollutants. \\
\hline
\end{tabular}


WHC-SD-EN-RD-010, REV. 0

\section{LIST OF TERMS (continued)}

T-BACT

T-RACT

Tri-Party Agreement

TSD

TWRS-EIS

WAC
Best Available Control Technology for Toxics

Reasonable Available Control Technology for Toxics

Hanford Federal Facility Agreement And Consent Order Treatment, Storage, And Disposal

Tank Waste Remediation System-Environmental Impact

Statement

Washington Administrative Code 


\section{REGULATORY ANALYSIS FOR THE USE OF UNDERGROUND BARRIERS AT THE HANFORD SITE TANK FARMS}

\subsection{BACKGROUND}

Retrieval of waste from the Hanford Site single-shell tanks (SSTs) represents a significant challenge for waste management personnel. In addition to considering waste retrieval options (e.g., hydraulic sluicing; a process that uses hot water to dislodge waste for subsequent vacuum removal), underground barrier systems also are being evaluated to mitigate releases of dangerous waste to the environment during retrieval activities.

The following underground barrier systems are being evaluated to determine whether their full scale construction and operation at the Hanford Site SST Farms is viable.

- A desiccant barrier would be created by circulating air through the subsurface soil to lower and then maintaining the water saturation below levels required for liquids to flow. Air and water vapors are collected at the surface, dehydrated to remove the water vapor, and then filtered to remove any contaminants or particulate matter. The dry air is then recirculated through the soil column.

- An injected materials barrier would be created by injecting materials such as grout or silica into the subsurface soils to form a barrier around and under a given tank or tank farm.

- A cryogenic barrier would be created by freezing subsurface soils in the vicinity of a tank or tank farm. This type of barrier may use a circulating brine solution or nitrogen to freeze the subsurface soil.

This document provides an analysis of the regulatory requirements that may impact full scale construction and operation of these underground barrier systems. In addition to potentially applicable regulatory requirements, the following sections provide a discussion of factors that should be considered throughout the barrier selection process, including disposition of secondary waste and potential impacts on final closure of the SSTs. Section 7.0 of this document provides a regulatory requirements summary along with information regarding the time required to obtain various permits and approvals. Additionally, Appendix A consists of a matrix of the requirements identified as being applicable to construction and operation of an underground barrier system. When a requirement is identified as being applicable, the matrix identifies the requirement of concern, the lead regulatory agency, and the restriction(s) imposed by that requirement, irrespective of the underground barrier system being considered. For each applicable requirement, a note is provided at the end of the matrix that provides additional detailed information for the identified requirement. 
Throughout this document, reference is made to federal and Washington State regulations. The federal regulations that implement the Resource Conservation and Recovery Act (RCRA) refer to regulated waste as hazardous waste; Washington State regulations of WAC 173-303 of the Washington Administrative Code (WAC) refer to regulated waste as dangerous waste. To eliminate confusion, this document will use the term dangerous waste when discussing waste subject to regulation in accordance with WAC 173-303. The one exception to this is when reference is made specifically to extremely hazardous waste, which is a state-only classification.

\subsection{REGULATORY STATUS OF THE SSTS}

The Hanford Site SSTs currently are operating under interim status. The U.S. Environmental Protection Agency (EPA) has determined that any unit that was in existence on the effective date of the RCRA regulations (November 19, 1980) and that filed a RCRA Section 3010 notification would be treated as if it had been issued a permit. These types of facilities are referred to as interim status facilities. Because the SSTs do not meet current regulatory requirements for dangerous waste treatment and storage tanks, they will be - closed under interim status and a Part B permit required by WAC 173-303-806 will not be developed.

WAC 173-303 establishes the requirements applicable to generators; transporters; and owners or operators of treatment, storage, and disposal (TSD) units. WAC 173-303-400(3)(a) specifies that the requirements for interim status TSD units shall be those requirements set forth by the EPA in 40 CFR 265, Subparts F through $R$ in the Code of Federal Regulations (CFR). Additionally, interim status TSD units must comply with Washington State's land disposal restrictions established in WAC 173-303-140 and the facility requirements in WAC 173-303-280 through 173-303-440.

Retrieval of SST waste is governed by the Hanford Federal Facility Agreement and Consent Order (Tri-Party Agreement) (Ecology et al. 1992), milestone M-45-00 and supporting target dates. This major milestone requires retrieval of as much tank waste as technically possible with tank waste residues not to exceed 360 cubic feet in each of the 100 series tanks, 30 cubic feet in each of the 200 series tanks, or the limit of waste retrieval technology capability, whichever is less. The Tri-Party Agreement also provides allowances for the U.S. Department of Energy (DOE) to be granted an exception to this retrieval criteria if a demonstration can be made to the Washington State Department of Ecology (Ecology) and the EPA that the removal criteria cannot be achieved.

Closure of the SSTs must be performed in accordance with an approved closure plan, which is scheduled to be submitted to Ecology by November 2004 as specified in milestone M-45-06-T01 of the Tri-Party Agreement. Section 5.3 of the Tri-Party Agreement states that all TSD units that undergo closure, irrespective of permit status, shall be closed in accordance with WAC 173-303-610. The closure standards of WAC 173-303-610 recently have been revised to require cleanup of dangerous waste and dangerous waste constituents in 
soil, ground water, surface waters and air to the cleanup levels established by the Model Toxics Control Act (MTCA) of WAC 173-340-700 through -760 methods A and B. For all structures, equipment, bases, liners, etc., the clean closure standards will be established by. the department in a manner that minimizes or eliminates post-closure escape of dangerous' waste constituents.

In the event that clean closure of the SSTs cannot be accomplished, the SSTs will be closed as a landfill, as required by 40 CFR Part 265.197(b). In this case, a closure plan that addresses closure of the SSTs as a landfill will be required. Additionally, post-closure care will be required for a period of at least 30 years, and must be performed in accordance with a post-closure permit.

\subsection{BENEFITS FROM USING UNDERGROUND BARRIERS}

Many of the SSTs have released mixed waste or are assumed to have released mixed waste into the environment. Because the SSTs are approaching the end of their design life, it is likely that additional releases will occur in the future. Therefore, an expeditious method of waste retrieval is needed to prevent additional releases of mixed waste into the environment. Sluicing has been identified as a candidate to accomplish the task of retrieving SST waste.

Concerns have been identified as to whether sluicing will increase the potential for releases of mixed waste into the environment. As a result, underground barriers are being evaluated as a method of minimizing impacts to the environment in the event of such releases during waste retrieval activities. Subsurface barriers may be used to slow the migration of contaminants sufficient to limit amount of mixed waste released and to allow potential follow-up remedial actions, as necessary. The use of subsurface barriers may also be used to meet or assist in meeting the general closure performance standards of WAC 173-303-610(2) as discussed in the following sections.

\subsubsection{Minimize the Need for Further Maintenance}

WAC 173-303-610(2)(a)(i) specifies that all closure activities will minimize the need for further maintenance. Use of an underground barrier system has the potential to minimize the quantities of mixed waste that may be released into the environment during waste retrieval activities. Depending upon the type of barrier system employed, contaminants released from the tanks into the underlying soils may be remediated during follow-up activities, if necessary. At this time, the specific type of barrier that might be used is undetermined, but may include a close-coupled system (i.e., a barrier designed to provide confinement around a single tank) or a stand-off system (i.e., a barrier designed to provide confinement around and entire tank farm). Either barrier system would potentially minimize environmental impacts to the environment during waste retrieval. Additionally, the barrier system may serve as a mechanism to reduce the potential for groundwater contamination resulting from future releases of mixed waste if waste were to remain within the tanks after closure is complete. 


\subsubsection{Control the Postclosure Escape of Dangerous Waste}

WAC 173-303-640(8) requires that upon closure of a tank system the owner or operator to remove or decontaminate all waste residues, contaminated containment system components (liners, etc.), contaminated soils, and structures and equipment contaminated with waste, and manage them as dangerous waste, as necessary. Subsurface barriers will allow waste retrieval activities to proceed while minimizing impacts on the environment. As discussed previously, depending upon the type of barrier used, follow-up remedial actions may be initiated to remediate releases resulting from waste retrieval activities that are contained in soil underlying the tanks but above the barrier system. Such activities would assist in meeting the general closure performance standard of WAC 173-303-610(2)(a)(ii), which requires the closure action to control, minimize, or eliminate to the extent necessary to protect human health and the environment, postclosure escape of dangerous waste, dangerous constituents, leachate, contaminated run-off, or dangerous waste decomposition products to the environment.

\subsubsection{Return the Land to the Appearance and Use of Surrounding Land Areas}

WAC 173-303-610(2)(a)(iii) requires closure actions to return the land to the appearance and use of surrounding land areas to the degree possible given the nature and extent of the previous dangerous waste activity. While an underground barrier system in and of itself will not meet this general performance standard, the use of such a barrier in conjunction with other closure activities may be helpful to achieve this requirement. As discussed previously, an underground barrier system may be beneficial in confining releases of waste during waste retrieval activities. Waste that is confined by the barrier system may be suitable for follow-up remedial or closure actions to remove contamination. Therefore, in certain instances clean closure of the area above such barrier system may be feasible if such an approach were agreed upon by the lead regulatory agency. In this case, underlying groundwater contamination, if any, could be deferred for remediation as part of the groundwater operable unit under the authority of CERCLA. If clean closure was to be accomplished, the land potentially could be restored to the appearance and use of the surrounding land use areas, as appropriate. 


\subsection{REGULATORY REQUIREMENTS}

Although there are no regulatory requirements that specifically require installation of an underground barrier system for existing tank systems, there are a number of requirements that will be triggered by the full scale construction and operation of such a barrier. Requirements that are most likely to impact construction and operation of an underground barrier system are discussed in this section and are organized in tabular form in Appendix A.

\subsection{LISTED WASTE CONCERNS}

The SSTs have received a variety of waste including dangerous waste listed as F001 through F005 in WAC 173-303-9904. Management of listed waste mixtures, waste derived from the management of listed waste, and listed waste contaminated environmental media may have considerable impacts on full scale construction and operation of an underground barrier system at the Hanford Site SST Farms. Regulations applicable to listed waste include the following.

MIXTURE RULE. The mixture rule establishes requirements for mixtures of a solid waste and a listed dangerous waste. This regulation is identified in

40 CFR 261.3(b)(2) and states that a mixture of a solid waste and a listed dangerous waste causes the entire mixture to be regulated as a listed dangerous waste. This rule remains applicable to such mixtures irrespective of the concentration of listed dangerous waste constituent(s) in the mixture. For example, mixture of tank waste and rags, debris, or any other solid waste causes the entire mixture to be regulated as a dangerous waste.

DERIVED-FROM RULE. This regulation is established at $40 \mathrm{CFR}$ 261.3(c) and essentially states that any waste generated from the treatment, storage, or disposal of a listed dangerous waste, including any sludge, spill residue, ash, emission control dust, or leachate is a listed dangerous waste. Waste that becomes subject to regulation by means of application of the derived-from rule is regulated as a listed dangerous waste irrespective of the listed dangerous waste constituent(s) in the waste. For example, if an underground barrier system is used that extracts waste from contaminated soil underlying a given tank farm, the wastewater could be regulated as a listed dangerous waste through application of the derived from rule.

CONTAINED-IN POLICY. The contained-in policy is based on an EPA determination that although environmental media are usually not solid waste they frequently enter the RCRA system because of contamination by RCRA listed waste. The contained-in policy states that environmental media (e.g., soils and groundwater) contaminated with a listed waste must be managed as if the media were a dangerous waste until it no longer contains the listed waste in question or until such time as the media is delisted. Under EPA's current policy, contaminated environmental media 
may be determined to no longer contain listed waste when the listed waste constituents in the media fall below site-specific, risk-based levels and the media does not exhibit a dangerous waste characteristic or fail the state criteria.

Ecology has adopted the EPA's contained-in policy and has established risk-based action levels that employ residential cleanup standards, using the calculations required by Model Toxics Control Act, to make contained-in determinations. Contingent management (e.g., allowing application of the contained-in policy provided the media is managed in a specific manner that further reduces risk to human health or the environment) may be considered when appropriate. In some cases, Ecology may determine that contingent requirements allow the site-specific risk-based action levels to be calculated according to the Model Toxics Control Act industrial land use standards.

In summary, listed waste contaminated environmental media that is excavated or generated during construction of an underground barrier system will require management as a listed dangerous waste unless Ecology determines that the soil in question does not contain listed waste constituents above residential health-based standards. To get a contained-in determination, a sampling and analysis plan must be developed and approved by Ecology and samples of sufficient quantity and quality must be obtained to characterize the media in question. Ecology will use the data obtained from the sampling efforts to make a contained-in determination. The management of listed waste contaminated environmental media and any other secondary waste generated during full scale construction and operation of an underground barrier system must be carefully considered before generation. It is anticipated that all three barrier types will generate a certain amount of secondary waste, in the form of contaminated media and others, that will require dangerous waste management. Minimizing this waste generation will be vital from a cost and scheduling perspective.

\subsection{UNDERGROUND BARRIER SYSTEM REQUIREMENTS}

The regulations in 40 CFR 265, Subpart J, "Tank Systems" establish the requirements for interim status tank systems used for the storage and/or treatment of dangerous waste. An owner or operator of a dangerous waste tank system may use one of four types of secondary containment identified in 40 CFR 265.193(d), including a liner external to the tank. The SSTs will not be upgraded to achieve compliance with the secondary containment requirements. Therefore, these requirements do not apply specifically to construction of an underground barrier of the type contemplated and have been included for informational purposes only. However, in considering design or performance standards for an underground barrier system it may be prudent to evaluate the criteria already established for external liners serving as secondary containment. Accordingly, external liners that are used to meet the secondary containment requirements must have the following characteristics:

- Designed or operated to contain one hundred percent of the capacity of the largest tank within its boundary 
- Designed or operated to prevent run-on or infiltration of precipitation into the secondary containment system unless the collection system has sufficient excess capacity to contain run-on or infiltration. Such additional capacity must be sufficient to contain precipitation from a twenty-five-year; twenty-four-hour rainfall 'event

- Free of cracks or gaps

- Designed and installed to surround the tank completely and to cover all surrounding earth likely to come into contact with the waste if the waste is released from the tank(s) (e.g., capable of preventing lateral as well as vertical migration of the waste).

The EPA has provided additional guidance on external liners used for secondary containment in 51 FR 25422. The external liners may be used to contain releases from above-ground, in-ground or underground tanks. Owners or operators who use external liners as secondary containment must ensure that the liner provides a complete envelope that will prevent both lateral and vertical migration of waste from the containment system. Finally, compatibility between the liner and the waste to be handled must be ensured so that the integrity of the liner will be maintained. According to EPA, specific liner performance standards should not be incorporated into the regulations because this type of guidance is best addressed in guidance documents. The requirements of 40 CFR 265.193(d)(1) apply only where liners serve as secondary containment. However, these standards may be appropriate guidance in selecting an underground barrier system design.

\subsection{EXPANSION OF EXISTING UNITS}

Any existing unit used for the management of dangerous waste must be operating under interim or final status. However, an existing facility may expand existing waste management activities while operating under interim status to allow for construction of additional waste management units: In order to accomplish this, a notice of intent (NOI) for interim status expansion must be submitted to and approved by Ecology. Expanding an existing unit (e.g., the SSTs) to incorporate additional waste management units may be necessary to facilitate management of secondary waste, such as contaminated wastewater or contaminated environmental media generated from full scale barrier construction and operation. Construction of a subsurface barrier in and of itself, however, does not require development of an NOI.

The regulatory requirements for development of an NOI, to allow an existing facility to expand under interim status, are identified by WAC 173-303-281. According to these regulations, a facility that is operating under interim status may expand TSD activities provided Ecology approves an application for expansion. To accomplish this, an NOI must be filed with Ecology at least 150 days before submittal of a revised Part A permit application for the proposed expansion. The NOI must include the following information required by WAC 173-303-281(3): 
- The name, address, and telephone number of the owner, operator, and corporate officers

- The location of the proposed facility or expansion on a topographic map with specifications as detailed in WAC 173-303-806(4)(a)(xviii)

- A brief description of the types and amounts of waste to be managed annually

- A brief description of the major equipment items proposed, if any, and the waste management activities requiring a permit or revision of an existing permit

- An environmental checklist from "SEPA Rules," WAC 197-11

- Demonstration of compliance with the sitting criteria as required under WAC 173-303-282(6) and (7). The site conditions with regards to satisfying the criteria are to be assessed as of the date of submittal of the NOI to the department

- For informational purposes, a complete summary of compliance violations of permit conditions at dangerous waste management facilities owned or operated by the applicant, its subsidiaries or its parent company, during the ten calendar years preceding the permit application. Along with the summary of compliance violations, as issued by appropriate state or federal regulatory agencies, the applicant shall also submit responses to past violations and any written correspondence with regulatory agencies regarding the compliance status of any dangerous waste management facility owned or operated by the applicant, its subsidiaries or parent company of the owner or operator. A more detailed compliance record must be provided upon request by the department

- For informational purposes, the need for the proposed facility or expansion shall be demonstrated by one of the methods of WAC 173-303-281(3)(a)(viii)(A) through (C)

- For informational purposes, it shall be shown how the capacity of the proposed facility or expansion will affect the overall capacity within the state, in conjunction with existing facilities in Washington.

The NOI must be filed with Ecology at least 150 days before filing an application for a permit or permit revision. An announcement that encourages public comment regarding the NOI must be placed in a daily newspaper within the area of the proposed facility or expansion for a minimum of 14 days before the NOI is filed with Ecology. Typically, preparation time for a NOI is two to four months, which does not include internal or external review time.

If Ecology denies an NOI for interim status expansion, a Part B permit for the unit in question will be required before construction of a proposed facility may begin. The time required to obtain a Part B permit is difficult to predict because there currently are no 
dangerous waste management units at the Hanford Site that are operating under an approved permit. Based on previous permitting activities performed at the Hanford Site, preparing and obtaining a Part B permit would require from four to six years. The NOI process only applies to new waste management units that may be required for the management of dangerous waste (e.g., secondary waste such as wastewater or contaminated soils) generated during construction and operation of an underground barrier system.

\subsection{USE OF REGULATED BARRIER MATERIALS}

To select a final barrier system, an evaluation will be required to determine whether the materials used as part of the barrier will be regulated as a dangerous waste upon closure of the tank farms. This is an important consideration because a material serving its intended purpose is not a waste until it has been used for its intended purpose and is then discarded or abandoned. Although regulated constituents contained within a barrier system would not be defined as a solid waste when the barrier is operational, those same constituents could be viewed as being abandoned upon closure of the tank farms when the barrier would no longer be serving its intended purpose. As a result, the ability to perform clean closure of a given tank or tank farm could be impacted and/or complete retrieval of the barrier could be required by Ecology.

The following is a brief discussion of the criteria used in performing a dangerous waste designation.

A solid waste may be regulated as a dangerous waste if it meets the definition of a listed dangerous waste, exhibits one or more dangerous waste characteristics or fails any of the state criteria. With regard to listed dangerous waste generated from specific and non-specific sources, a review of the listing criteria indicates that constituents associated with an underground barrier system will not meet the source-based definition for waste generated from specific and non-specific sources. Listed waste generated from specific and nonspecific sources are defined in WAC 173-303-9904 and do not include waste as constituents of a barrier system.

The listed waste codes for discarded commercial chemical products, which are identified in WAC 173-303-9903, will not apply to the final barrier form. The listing for discarded commercial chemical products only applies to commercially pure grades of listed chemicals, technical grades, and formulations in which the listed chemical is the sole active ingredient. This listing also applies to residues of commercial chemical products remaining in containers or inner liners and residues or contaminated soil, water or other debris resulting from the cleanup of a commercial chemical product. The discarded commercial chemical products listing does not include chemical mixtures where the listed chemical is not the sole active ingredient, and does not apply to chemicals that have been used for their intended purpose. 
An evaluation of barrier materials should be made to ensure that barrier constituents will not exhibit a dangerous waste characteristic(s) upon disposal or abandonment of the barrier. The characteristics of dangerous waste mixtures, defined in WAC 173-303-090(5) through -090 (8), include ignitability, reactivity, corrosivity, and toxicity, respectively. While it is unlikely that injected barrier materials will exhibit any of the dangerous waste characteristics, a thorough review of available information should be conducted to verify this assumption. Information obtained from the manufacturer of the barrier materials, including material safety data sheets, may provide adequate information to perform this designation. Particular attention should be paid to any formulation containing heavy metals and/or organic compounds.

The state dangerous waste criteria of WAC 173-303-100 include toxicity, persistence, and carcinogenicity. Barrier materials should be evaluated against these designation criteria to ensure that such materials would not be regulated as dangerous waste upon completion of waste retrieval when the barrier no longer serves its intended purpose.

The toxicity criteria is based on the toxicity of a given chemical constituent rather than on a leach test as required by the toxicity characteristic leaching procedure of WAC 173-303-090(8). The first step in this process is to determine the toxicity of the chemicals in question based on a review of the Registry of Toxic Effects of Chemical Substances (NIOSH 1991). Based on the toxicity, a chemical will be assigned as a category $\mathrm{X}, \mathrm{A}, \mathrm{B}, \mathrm{C}$, or $\mathrm{D}$ toxic compound with $\mathrm{X}$ being the most toxic and $\mathrm{D}$ being the least toxic. Finally, equivalent concentrations are calculated to determine the regulatory status of a given chemical or compound.

A chemical or compound may be designated as persistent if the waste contains halogenated hydrocarbons (HHs) and/or polycyclic aromatic hydrocarbons (PAHs). To determine whether a waste is designated for persistence, add the concentration percentages for all of the waste's significant halogenated hydrocarbons. A waste will be designated as a dangerous waste if the HHs are present at concentrations of 0.01 to 1.0 percent. A waste will be designated as an extremely hazardous waste if HHs are present at concentrations in excess of 1.0 percent. To determine whether a waste is regulated because of the presence of PAHs, add the concentration percentages for all of the waste's significant polycyclic aromatic hydrocarbons with more than three rings and less than seven rings. A waste will be designated as a dangerous waste if the PAHs are present at greater than 1.0 percent.

The carcinogenicity designation is based upon information contained in the National Institute for Occupational Safety and Health (NIOSH) Registry or other scientific literature that specifies a given chemical or compound as an International Agency for Research on Cancer (IARC) human or animal sufficient or limited carcinogen. A waste containing any one IARC carcinogen in excess of 0.01 percent will be designated as a dangerous waste. Similarly, if a waste contains more than one IARC carcinogen, the waste will be designated as a dangerous waste if the sum of all IARC sufficient and limited carcinogens exceeds 1.0 percent of the 
waste quantity. Finally, a waste may be designated based upon carcinogenicity as an extremely hazardous waste if any one IARC sufficient carcinogen exceeds 1.0 percent of the waste quantity.

A preliminary evaluation of the regulatory status of barrier constituents should be performed irrespective of the type of barrier selected for construction. The type of underground barrier system selected may have impacts on final closure of the SSTs, as discussed in Section 9.0 and may result in significant waste management issues if the final barrier requires retrieval and disposal as a dangerous or mixed waste, as part of the closure process.

\subsection{MANAGEMENT OF SECONDARY WASTEWATER}

Construction and operation of an underground barrier system may generate dangerous waste requiring management in accordance with applicable state and federal regulations. In particular, vapor extraction of the soil column underlying the SSTs, by means of the desiccant barrier system, may result in the generation of listed waste contaminated wastewater. The injected materials and cryogenic barriers also have the potential to generate secondary waste in the form of contaminated wastewater. However, the volume of wastewater that will be generated by those two barriers is expected to be minimal compared to the volumes of wastewater expected to be generated by the desiccant barrier system. The remainder of this section focuses on management options for listed waste contaminated wastewater that may be generated from construction and operation of an underground barrier system, in particular the desiccant barrier system.

With regard to contaminated wastewater, this waste would carry the listed dangerous waste codes of F001 through F005, as discussed in Section 2.2 and, thus, require management as a listed dangerous waste. Sections 2.5.1 through 2.5.4 discuss potential options for management of this contaminated wastewater. Issues associated with delisting and land disposal restrictions (LDR) are discussed in Sections 2.6 and 2.7, respectively.

\subsubsection{Manage Contaminated Wastewater in New Storage Tanks}

As discussed in Section 2.2, any unit used for the management of dangerous waste must be operating under interim or final status. If construction of additional dangerous waste management units is required for the treatment, storage or disposal of such waste, a NOI for interim status expansion must be completed. A NOI must be submitted to Ecology at least 150 days before submittal of a revised Part A permit for the unit in question. Additionally, two to four months are required for development of a typical NOI.

According to 40 CFR 270.73(g), for owners and operators of interim status facilities, interim status terminated on November 8, 1992 for any facility (other than a land disposal facility) that achieved interim status before November 8, 1984, unless the owner or operator of the 
facility submitted a Part B application for a RCRA permit for the facility by November 8 , 1988. However, the Tri-Party Agreement provides a permitting and closure schedule for TSD units at the Hanford Site, including new TSD units. Some examples of where Ecology has allowed interim status expansion for new units include the Hanford Waste Vitrification Plant and the new double-shell tanks (DSTs), among others. At this time, there is no indication how long Ecology will continue to grant interim status expansion for new units and this matter is subject to negotiation. If a proposed facility is denied interim status expansion, construction of such facility may not commence until a Part B permit for that facility has been approved by Ecology. The Part B permit approval process can be expected to take anywhere from 3 to 6 years.

\subsubsection{Manage Wastewater in Existing Tanks}

An alternative to constructing new storage tanks may be to discharge the contaminated wastewater to one or more of the existing SSTs or DSTs. To accomplish this transfer, the waste codes associated with the contaminated wastewater must be identified on the associated SST or DST Part A Permit. Any contaminants in the wastewater would be assumed to have originated within the SSTs or DSTs.

Ecology may have concerns with adding wastewater to one or more of the SSTs that have already been interim stabilized. The addition of free liquids would be counterproductive to interim stabilization activities and may impact Tri-Party Agreement milestones for completion of such activities. Additionally, existing regulations in 40 CFR 265.193 preclude the use of any tank system that does not have secondary containment after January 12, 1989 . On the other hand, Ecology may allow the transfer of contaminated wastewater to an SST that has not been interim stabilized as a mechanism to facilitate waste retrieval from a given tank or tank farm. Ecology concurrence is required on any such proposal as there may be a potential to impact Tri-Party Agreement milestones and because existing regulations would otherwise preclude such actions.

From a technical perspective, it may be feasible to transfer contaminated wastewater to one or more of the DSTs by means of existing diversion boxes. At this time, volume restrictions have been established for waste transfers to the DSTs. These restrictions are based on priority, such as the.immediate need to pump a leaking SST, waste generation projections for on-site chemical processing facilities, and existing waste tank volume. Decisions regarding waste transfers to the DSTs are made on a case-by-case basis, with consideration of waste volume projections from across the site.

In addition to the above restrictions, limitations established as part of "Public Law 101-510, Section 3137" prohibit the addition of high-level waste (HLW) to watch-list tanks except for small amounts to be removed and returned to a tank for analysis, unless the Secretary of the DOE determines that no safer alternative exists or that the tank does not pose a serious 
potential for a release of HLW. Significant documentation is required before adding high level waste to one of these tanks, including preparation of a safety assessment, environmental assessment and an engineering evaluation of alternatives.

A memorandum from Leo P. Duffy, U.S. Department of Energy - Headquarters (DOE-HQ) has authorized water additions to the Hanford Site's watch list tanks as a routine Tank Farm operation until completion of certain upgrade activities or change in Tank Farm operating practices. The types of activities addressed in the referenced memorandum that may introduce water to a watch list tank include routine maintenance and testing activities (e.g., flushing transfer lines upon completion of waste transfers), hydrostatic tests of the transfer lines before pumping, and temperature control activities. Approval by the Secretary of the DOE would be required before addition of wastewater to a watch list tank.

\subsubsection{Manage Wastewater in the Liquid Effluent Retention Facility}

A possible option for disposition of contaminated wastewater generated by use of the desiccant barrier system may be to discharge such wastewater to the Liquid Effluent Retention Facility (LERF) Basins. The LERF Basins are currently operating under interim status and consist of three 24.6-million-liter (6.5-million-gallon) capacity basins and a fourth basin of the same capacity that has not been and is not expected to be completed. The current Part A Permit for the LERF Basins includes the listed waste codes F001 through F005 and the state-only waste code of WT02 for toxic dangerous waste. However, the LERF Part A Permit does not include characteristic dangerous waste codes. As a result, if contaminated wastewater is deemed to exhibit one or more dangerous waste characteristic a revision to the LERF Part A Permit would be required before transfer of contaminated wastewater to the LERF Basins. The LERF Part A Permit would also require a revision if the wastewater is determined to be regulated as an extremely hazardous waste based upon toxicity, persistence, or carcinogenicity.

Use of the LERF Basins may be precluded for the following reasons. First, it is not clear at this time whether sufficient storage space is available to accommodate storage of contaminated wastewater generated during use of the desiccant barrier system. One option for resolving this issue would be to complete the fourth basin and place it into service. However, this would require a revision to the existing LERF Basin Part A Permit as well as development and approval of an NOI for interim status expansion to address the increase in storage capacity. Additionally, revisions to the latest version of the Part B permit application for this unit would be required to address the additional unit as well as appropriate waste analysis information associated with the contaminated wastewater.

Secondly, it is not clear, at this time, how the wastewater would be subsequently managed if it were transferred to the LERF Basins. One proposal would be to treat the wastewater in the 200 Area Effluent Treatment Facility (ETF) and discharge the treated wastewater to the ground in accordance with a wastewater discharge permit issued pursuant to WAC 173-216. 
Because the wastewater in question will be contaminated with listed dangerous waste, this option will not be viable unless the wastewater is included in the existing delisting petition for 242-A Evaporator process condensate. At this time, this waste stream is not included in the delisting petition for the 242-A Evaporator process condensate. Additional detailed information regarding delisting is provided in Section 2.6.

Finally, the LDR regulations require a thorough evaluation before pursuing this option. In general, the Tri-Party Agreement provides specific language regarding management of mixed waste and compliance with LDR. Milestone M-26-03 states that discharges of effluents containing dangerous waste subject to the land disposal restrictions other than process condensate from the 242-A Evaporator to LERF is prohibited. This is because restricted dangerous waste must be treated to appropriate LDR treatment standards before being placed into a land disposal unit (e.g., landfill, surface impoundment, etc.). A special agreement or revisions to existing Tri-Party Agreement milestones may be required in order to use the LERF Basins for the storage of restricted dangerous waste. Additional detailed information regarding compliance with LDR regulations is provided in Section 2.8 .

\subsubsection{Manage Wastewater in the Purgewater Modutanks}

A possible option for management of contaminated wastewater would be to collect the wastewater and transfer it to the 600 Area Purge Water Storage and Treatment Facility (Modutanks). This unit consists of six above ground 3.8-million liter (1-million gallon) capacity tanks with a total capacity of 22.7-million liters (6-million gallons). The Part A permit for this unit identifies this unit as a miscellaneous unit and identifies the listed waste codes F001 through F003 as waste that may currently be received in this unit. Because the SSTs have received F001 through F005 listed dangerous waste, a revision to the Purgewater Modutank Part A Permit would be required to include the additional waste codes of F004 and F005. Additionally, the process description associated with this Part A permit would require modification to include a discussion of the source and type of waste being discharged to this unit. As currently written, this Part A permit only allows the discharge of purgewater to this unit.

As with management of this wastewater in the LERF Basins, ultimate disposition of such wastewater is not clear at this time. Treatment by means of the ETF may be an option provided this waste stream is included in the existing delisting petition or otherwise delisted. The delisting of this waste is necessary because the effluent from the ETF will be discharged to the ground in accordance with an 216 Permit and dangerous waste cannot be discharged directly to the ground. See Section 2.6 for specific information regarding delisting of a listed dangerous waste. 


\subsection{DELISTING ISSUES}

The current delisting petition for liquid from the 200 Area ETF was written to allow evaporator condensate to be treated and disposed of as non-dangerous waste provided that certain concentration limits are met in the treated effluent. In addition, an attempt was made to write the petition in a manner that covers the potential for treating and disposing of waste streams other than the evaporator condensate by means of the ETF. It remains to be seen whether EPA will approve a broad delisting petition of this nature or restrict approval only to specified input streams (e.g., the evaporator condensate).

Even if EPA eventually does approve the broad scope delisting petition, it would be necessary to verify that each listed waste stream to be treated and subsequently delisted and disposed of falls within the purview of an approved delisting petition. This would mean that the waste would have to (1) be within the listed waste codes discussed in the petition - a likely occurrence assuming that the only assigned listed waste codes are a consequence of "mixing" with the evaporator condensate in the LERF, and (2) contain no dangerous waste constituents other than those identified in the delisting petition. This latter criterion could be significant in that different waste streams could contain different dangerous constituents even if the streams are assigned identical dangerous waste codes. In such a case, the delisting petition would not be valid. Of course, the option exists to modify the delisting petition to include additional streams with other dangerous constituents. Such an effort would, however, be costly and very time consuming.

It is important to note that the wastewater currently in storage in the Modutanks is not considered to be listed dangerous waste. However, listed waste contaminated wastewater generated by use of the desiccant barrier system would be defined as a listed dangerous waste until such time as a contained-in determination is made or the waste is delisted. Pursuing a delisting petition for such wastewater would be costly and very time consuming.

\subsection{LAND DISPOSAL RESTRICTIONS}

The land disposal restrictions (LDR) provisions were established by Congress as a part of the Hazardous and Solid Waste Amendments to RCRA. Among other things, these amendments prohibit the land disposal of dangerous waste unless the waste meets specified standards. Since the term "land disposal" is defined to include any placement of dangerous waste in a surface impoundment, and since the LERF units are surface impoundments and the 242-A Evaporator condensate could include dangerous waste that does not meet the LDR treatment standards, the LDR prohibitions would appear to preclude use of the LERF. This apparent problem was addressed, however, by provisions established in the first amendment of the Tri-Party Agreement.

Milestones M-26-03 and M-26-04 of the Tri-Party Agreement specifically allow discharge of 242-A Evaporator process condensate to the LERF units provided that certain constraints are met. Milestone M-26-03 prohibits use of LERF for any waste subject to LDR other than the 
evaporator condensate. This milestone further requires that evaporator condensate discharges cease by December, 1994. Milestone M-26-04 requires that all dangerous waste residue be removed from the 242-A Evaporator LERF units by June, 1995.

\subsubsection{Federal LDR Considerations}

Storage of evaporator condensate (a potentially LDR prohibited waste) in the LERF is allowed only as a result of the special provisions of the Tri-Party Agreement. These provisions restrict LDR storage to evaporator condensate and establish a schedule for ceasing even these discharges (December, 1994) and cleaning out the units (June, 1995).

Before placing any other dangerous waste into the LERF Basins, an evaluation would be required to determine if the waste meets the LDR standards. If these standards are not met, placement in the LERF pending treatment would be prohibited unless a new Tri-Party Agreement milestone is negotiated for such activity. Dangerous waste that met the LDR standards would not be precluded from storage in the LERF with the possible exception of impermissible dilution issues described in Section 2.7.2.

The EPA has established an exception from LDR standards regarding placement of waste in surface impoundments when actual treatment occurs in the impoundment. In such cases, a variety of conditions must be met. These include a requirement to remove, at least annually, any residues that do not meet the LDR treatment standards or any listed waste residues. Additionally, treatment must actually occur in the unit. There is no treatment aspect associated with the planned storage of evaporator condensate in the LERF units. However, proposals that include an aspect of waste treatment in the LERFs could satisfy the exemption criteria. In any such cases, administrative activities, such as gaining regulator concurrence on the revised Part A Permit to document the treatment activity, would be necessary.

\subsubsection{Impermissible Dilution}

Compliance with LDR standards must be accomplished by means of legitimate treatment, and not as a consequence of impermissible dilution. A rather complicated framework exists for determining whether or not mixing of waste streams constitutes impermissible dilution as opposed to centralized accumulation before appropriate treatment (the latter being an acceptable waste management practice). Each waste stream potentially mixed in the LERF would need to be evaluated on a case-by-case basis to determine if the action represents impermissible dilution.

In general, it is impermissible to mix waste streams unless it can be shown that such mixing is appropriate for all waste streams undergoing mixing given the subsequent treatment processes. Additionally, such mixing would not be allowable if it resulted in dilution of a heavily concentrated waste stream(s) for which a different treatment process is more suitable. 
Impermissible dilution also would occur if a waste stream not requiring or amenable to treatment by a particular process is mixed with a stream for which the planned treatment is appropriate and necessary.

With regards to the potential for mixing specific dangerous waste in LERF it would be necessary to verify, before mixing, that (1) the subsequent treatment process will be appropriate to both streams and (2) the effectiveness of the subsequent treatment process will not be adversely affected by mixing of the streams.

As an example, consider mixing of two organic bearing waste that are both amenable to treatment in the ETF. Mixing would not be permissible if the organic concentrations in the two streams is so different that the performance of the ETF will be significantly lessened for either of the streams or if a treatment technology other than that encountered in ETF will be more suitable for either of the streams. On the other hand, if ETF performance will not be adversely impacted and the ETF treatment is suitable for the individual waste, mixing generally would be allowed.

As a second example, consider mixing of two organic-bearing waste streams, one of which also includes inorganic constituents requiring treatment by a method other than ETF. In such a case, mixing would again be allowed presuming that the performance of the ETF for the organic content of both streams is not adversely affected and such mixing does not adversely affect subsequent treatment of the mixture to address the inorganic constituents. Of course, such mixing necessarily would commit the entire stream to eventual treatment for the inorganic constituents. If the mixing would preclude or hinder eventual treatment of the stream requiring treatment for inorganic constituents, then the mixing would be considered impermissible dilution.

As a final example, consider mixing of two streams, one that requires treatment for organics and another that requires no treatment. In the July 8, 1987, Federal Register preamble, EPA states that it would "distinguish the case where a waste not requiring treatment or not aiding in treatment is mixed. This would be impermissible dilution, as it would merely dilute dangerous constituents into a larger volume of waste to lower constituent concentrations" (52 FR 25766). Thus, EPA considers mixing of streams in this manner to be impermissible dilution.

\subsubsection{State Land Disposal Restriction Considerations}

WAC 173-303-140 establishes LDR that are, in many cases, distinct from the Federal LDRs. These include a prohibition against land disposal of any extremely hazardous waste. Unlike the Federal LDRs, however, the state standards apply only in cases where the intent is to leave the waste in place at closure. Presuming that the intended use of the LERF units is storage before treatment and that, at closure, the LERF units will be emptied, the state LDRs should not create any particular impediments to use of the LERFs. 


\subsection{CLOSURE ISSUES}

Upon closure of a tank system, the owner or operator is required to remove or decontaminate all waste residues, contaminated containment system components, contaminated soils, and structures and equipment contaminated with waste, and manage them as dangerous waste unless the criteria of WAC 173-303-070(2)(a) apply. If the owner or operator demonstrates. that not all contaminated soils can be practicably removed or decontaminated, then the owner or operator must close the tank system and perform post-closure care in accordance with the closure and post-closure care requirements for landfills. In such cases, a tank system will be determined to be a landfill and the owner or operator will be required to comply with the requirements for landfills specified in WAC 173-303-610 and 173-303-620.

The type of underground barrier system chosen may have considerable impact on the ability to perform clean closure at a given tank farm: Installation of an injected materials barrier, for example, may preclude or cause significant difficulty with achieving the clean closure performance standard or characterizing the extent of contamination to determine whether clean closure is practicable. Additionally, Ecology could require removal of the underground barrier system as part of the closure process in order to ensure that underlying soils have been adequately characterized. The management of potentially large volumes of waste associated with this type of activity must be considered in the planning phase. On the other hand, the desiccant barriers and cryogenic barriers appear to have limited impacts on the final closure of the tanks because there are no injected materials that may require removal upon closure of the SSTs. Agreements with Ecology on these closure issues should be pursued before installation of any underground barrier system. 


\subsection{WASTEWATER DISCHARGES}

The State of Washington has established regulations in WAC 173-216 that govern the discharge of waste materials from industrial, commercial, and municipal operations into ground and surface waters of the state and into municipal sewer systems. Any wastewater discharge to the soil column that may adversely impact the groundwater has been determined to be subject to the permitting requirements of WAC 173-216. An owner or operator of a facility discharging wastewater under the provisions of a WAC 173-216 permit must use best available technology/all known available and reasonable treatment.

Existing wastewater streams at the Hanford Site will be permitted under WAC 173-216, in accordance with a schedule established in Consent Order DE 91NM-177a between the U.S. Department of Energy, Richland Operations Office, and Ecology. This consent order establishes a schedule for obtaining WAC 173-216 permits for 33 key wastewater streams that currently discharge to the soil column. Additional wastewater streams that will be discharged to the soil column may require revisions to the Tri-Party Agreement and/or consent order DE 91NM-177a.

It is important to note that the discharge of wastewater to the ground will be allowed only if such wastewater is not classified as a dangerous waste. Wastewater generated from construction and operation of an underground barrier system most likely will be classified as a listed dangerous waste because of the presence of listed waste constituents classified as F001 through F005 in accordance with WAC 173-303-9904. It may be possible to delist this wastewater and discharge the resulting wastewater to the ground in accordance with a WAC 173-216 permit. It is important to note that, while the desiccant barrier system may be expected to generate the largest quantities of wastewater, any wastewater generated from use of the injected materials or cryogenic barrier that will be discharged to the ground will also require a WAC 173-216 permit and must also be delisted by the EPA. 
WHC-SD-EN-RD-010, REV. 0

This page intentionally left blank. 


\subsection{AIR EMISSIONS}

An evaluation of potential air emissions will be required irrespective of the type of underground barrier system chosen for construction and operation. Because the details regarding the potential emissions of regulated constituents associated with full scale barrier construction and operation are not yet known, a broad analysis of potentially applicable air emission regulations has been provided in this section.

\subsection{NATIONAL EMISSION STANDARDS FOR HAZARDOUS AIR POLLUTANTS, 40 CFR 61, SUBPART H}

Radionuclides were designated as hazardous air pollutants in Section 112 of the Clean Air Act (CAA) on December 27, 1979, and EPA promulgated standards for radionuclide emissions on February 6,1985. Therefore, radionuclide air emissions associated with full scale construction or operation of an underground barrier system will be regulated under 40 CFR 61, Subpart H, "National Emission Standards for Hazardous Air Pollutants (NESHAPs) of Radionuclides Other Than Radon from Department of Energy Facilities."

Application for prior approval of construction under 40 CFR 61.07 is required for any construction or modification of a radionuclide air emissions source. Normally, an exemption from the prior approval is allowed if the estimated maximum dose to any member of the public added by the new construction would be less than 0.1 millirem per year. A withdrawal of the exemption was made by the EPA, effective December 2, 1992, because the EPA determined that the Hanford Site was not eligible for the exemption according to the conditions specified at 40 CFR 61.96. EPA determined that all Hanford Site sources of emission had not been adequately assessed for compliance with EPA requirements for continuous emission measurement. The EPA withdrawal will be lifted after full compliance with the emission measurement requirements. This may be as late as fiscal year 1996.

An application for approval of construction must include technical information describing the proposed nature, size, design, operating design capacity, and method of operation of the source, including a description of any equipment to be used for control of emissions. Such technical information shall include calculations of emission estimates in sufficient detail to permit assessment of the validity of the calculations.

According to the 40 CFR 61, the EPA will notify DOE of approval or intention to deny approval of construction within 60 days after receipt of all appropriate information. Additional notifications are required once construction approval is granted, such as notification of intent to startup 30-60 days before startup and another notification of actual startup within 15 days following startup. 


\subsection{RADIATION PROTECTION-AIR EMISSIONS, WAC 246-247}

The State of Washington Department of Health (DOH), Air Emissions and Defense Waste Section is authorized to implement regulations regarding radionuclide emissions from DOE facilities. According to WAC 246-247-050, the owner or operator of each source of airborne radionuclide emissions, including DOE Facilities, shall register the source with the department. Upon a determination that registration of a particular source meets Ecology and $\mathrm{DOH}$ regulations, the $\mathrm{DOH}$ will issue a permit authorizing the emission source with such appropriate terms and limitations. Permits are required by WAC $246-247-060$ for the release of radionuclides to the ambient air.

According to WAC 246-247-070, construction shall not begin on any new source that is required to be registered, until a notice of construction has been approved. The construction, installation or establishment of a new regulated source of emissions shall use best available radionuclide control technology (BARCT).

\subsection{CONTROLS FOR NEW SOURCES OF TOXIC AIR POLLUTANTS, WAC 173-460}

WAC 173-460 limits emissions of approximately 690 toxic air pollutants (TAPs). An owner or operator of a facility that will be a new TAP source is required to submit a notice of construction to Ecology to allow for a new source review. This notice of construction and new source review will apply only to the new emissions unit and the TAPs emitted from that unit. These regulations require emissions of TAPs to be quantified in such detail as to determine compliance with the rule's provisions. After emissions have been quantified, a comparison of those TAP emissions that are either increased or where there were previously no emissions from the source is made against the small quantity emission rates. If the emission rate of the TAP is less than the small quantity emission rate a notice of construction is not required. However, a notice of construction is required when the emission rate is above the associated small quantity emission rate.

Dispersion modeling will be used to determine if the facility can meet "acceptable source impact levels" (ASILs) for Class A TAPs (carcinogenic compounds) and Class B pollutants (other toxics). An ASIL for any Class A TAP will be determined using an acceptable cancer risk level $(1$ in $1,000,000)$, while Class B ASILs will be based on thresholds for toxic effects. If a facility cannot demonstrate Class A or Class B TAP source compliance, the WAC $173-460$ has provisions for petitioning Ecology to perform a second tier analysis to determine risk for the specific circumstance.

The WAC 173-460 regulations also specify the level of control technology that must be implemented, depending on whether the sources are modifications to exiting units or new sources. For existing sources, only reasonably available control technology for toxics (T-RACT) is required. However, best available control technology for toxics (T-BACT) is 
required for increases in emissions from specified new sources. The notice of construction, including the determination of T-BACT, must be approved by Ecology before beginning construction of the new source. : 
WHC-SD-EN-RD-010, REV. 0

This page intentionally left blank. 


\subsection{NATIONAL ENVIRONMENTAL POLICY ACT}

The National Environmental Policy Act of 1969 (NEPA) requires federal agencies to prepare detailed statements [e.g., environmental impact statements (EIS)] assessing the environmental impacts of and alternatives to proposed major federal actions that may significantly affect the environment. In addition, all federal agencies are required to develop methods and procedures to ensure that environmental considerations are factored into all decision making processes. The Council on Environmental Quality provides oversight to federal NEPA compliance issues and has established implementing NEPA regulations in 40 CFR 1500 through 1508.

\subsection{CATEGORICAL EXCLUSION AND ACTION DESCRIPTION MEMORANDUM}

The first step of a NEPA evaluation is to determine whether the proposed activity can be covered by a categorical exclusion (CX). If the proposed action meets the criteria as defined in 10 CFR 1021, Subpart D, Appendix B, for a categorical exclusion, an information bulletin is prepared describing the proposed action and identifying the applicable action category that allows the exclusion.

If a proposed action is not covered by a categorical exclusion, an action description memorandum (ADM) will be prepared. ADMs are concise documents including a discussion of the following information: (1) the purpose and need of the proposed action, (2) a brief but concise description of the proposed action, (3) a brief description of the potentially affected environment, and (4) potential environmental issues associated with the proposed action. The ADM serves as the basis for the DOE to determine the appropriate level of NEPA documentation required [e.g., an environmental assessment (EA) or an EIS].

\subsection{ENVIRONMENTAL ASSESSMENT}

An EA has the following three defined functions.

- To provide sufficient information to allow the DOE to determine whether a proposed action requires preparation of an EIS or a finding of no significant impact (FONSI).

- To provide an interdisciplinary review of the proposed action and alternatives to the proposed action.

- To facilitate preparation of an EIS when one is required. 
Based on the information contained in an EA, a decision will be made on the next course of action. A determination will be made to prepare an EIS if the proposed action will significantly affect the environment. If the proposed action is not a major action and will not significantly affect the environment, a FONSI is prepared.

\subsection{ENVIRONMENTAL IMPACT STATEMENT}

When an EIS is required the following sequence occurs.

1. An NOI is published in the Federal Register announcing the intent to draft an EIS. The NOI invites written comment and public testimony on the scope and purpose of the EIS.

2. As a result of scoping, an implementation plan is published. Upon approval of the implementation plan, a draft EIS is prepared.

3. Upon completion of the draft EIS, the draft is made available to the public for review and comment. Comments are incorporated into the draft EIS, and the EIS is finalized and made available to the public for review.

4. No sooner than 30 days after public notice of the availability of the final EIS, the DOE can publish its record of decision, which details the decisions reached in the EIS and the reasons for those decisions.

\subsection{REQUIRED LEVEL OF NEPA DOCUMENTATION}

The level of NEPA documentation required will depend on whether the proposed action constitutes a hot demonstration or full scale construction and operation. The NEPA Documentation Group expects that an ADM/EA will be the level of NEPA documentation required for hot demonstration of an underground barrier system. For full scale construction and operation of an underground barrier system, the environmental impacts will be discussed in the Tank Waste Remediation System - Environmental Impact Statement (TWRS-EIS) currently being developed. The reason for this is because hydraulic sluicing may cause tank waste to be released into the environment, thereby increasing the levels of soil contamination. As a result, construction and operation of an underground barrier system has been determined to be a connected action to waste retrieval for NEPA purposes. A record of decision for the TWRS-EIS is expected to be issued by the middle of 1996.

Actions that do not result in significant environmental impacts are concluded with development and issuance of a finding of no significant impact. In the past, DOE-HQ has determined the level of NEPA documentation required for a given proposed action. However, recent efforts to streamline the regulatory review process have resulted in a transition of NEPA decision making authority from the U.S. Department of Energy, 
Headquarters (DOE-HQ) to U.S. Department of Energy, Richland Operations Office (RL). This transition of authority is expected to expedite the DOE review and approval process. Preparation and approval of an EA traditionally have taken anywhere from 6 to 14 months depending on the scope of the proposed action. 
WHC-SD-EN-RD-010, REV. 0

This page intentionally left blank. 


\subsection{STATE ENVIRONMENTAL POLICY ACT}

Any action requiring a permit or license approval will require a State Environmental Policy Act (SEPA) evaluation. SEPA applies to any project or proposal that meets the definition of an "action" in the SEPA rules. The SEPA rules define an "action" in WAC 197-11-704 as being either project or non-project actions. Project actions involve a decision on a specific project, such as a construction or management activity located in a defined geographic area. Projects are limited to Ecology's decision to license, fund, or undertake any action that will directly modify the environment.

\subsection{COVERED ACTIONS}

SEPA requirements are triggered when a covered action is proposed that requires permit or license approval. For the purposes of constructing an underground barrier system, Ecology will be the lead agency. The SEPA compliance must be completed before Ecology makes a decision on a permit or license, and a SEPA checklist must accompany the permit or license when transmitted to Ecology for approval. A permit or license may be conditioned or denied based on information contained in the SEPA checklist or subsequent SEPA documentation. Compliance with SEPA is required for covered actions in addition to the normal permits or approvals that may be required for a given project. A standard SEPA checklist is provided in WAC 197-11-960.

Certain actions are categorically exempt from the SEPA evaluation process in WAC 197-11-800. These categorical exemptions apply to specific projects and include minor new construction and certain repair, remodeling, and maintenance activities. No further action is required on the part of the permittee for an activity that is determined to be categorically exempt from the SEPA evaluation process. In addition, Ecology is not required to document that a proposal is categorically exempt but may note on a permit application that a given proposal is categorically exempt or place such a determination in their files, as stated in WAC 197-11-305(2).

\subsection{THRESHOLD DETERMINATIONS}

When a SEPA evaluation is required for a given project, Ecology will make a threshold determination by deciding if the proposed project is likely to have significant adverse impacts on the environment. If Ecology determines that a project will have significant adverse environmental impacts, an EIS will be required. If the project in question will not have significant adverse environmental impacts or if the impact can be mitigated, a determination of non-significance (DNS) will be issued by Ecology.

The requirements for making a threshold determination are identified at WAC 197-11-330. The threshold determination is usually based on a review of the SEPA checklist. As part of 
the threshold determination process, Ecology should determine whether all or part of the proposal and associated impacts could be incorporated by reference. In the past, Ecology has accepted EAs and EISs as being equivalent to SEPA requirements and has not required additional SEPA evaluations or documentation.

\subsection{DETERMINATION OF NON-SIGNIFICANCE}

In the event that Ecology determines that a proposal will not have probable significant adverse environmental impacts, a DNS will be issued. Under certain circumstances identified at WAC 197-11-340(2)(a), a DNS must be issued with a 15-day comment period. The date of issuance for the DNS is the date the DNS is sent to Ecology, affected tribes, and the public.

If the proposed project does not meet the criteria of WAC 197-11-340(2)(a), the DNS may be issued without undergoing the public comment period. In this case, public notice is not required nor must the DNS be circulated to those groups identified above.

\subsection{REQUIRED LEVEL OF SEPA DOCUMENTATION}

The required level of SEPA documentation will depend upon whether the covered action constitutes a hot demonstration or full scale construction and operation. If the covered action constitutes a hot demonstration, a SEPA checklist will be required for any permit application or request for approval from Ecology. The SEPA checklist is prepared by the NEPA Documentation Function and accompanies the permit application or request for approval. For full scale construction and operation of an underground barrier, the TWRS-EIS will satisfy the SEPA requirements because Ecology and DOE are cooperative lead agencies for the TWRS-EIS. 


\subsection{REGULATORY REQUIREMENTS SUMMARY}

The following is a summary of the permitting and notification requirements contained in Sections 2.0 through 6.0 of this document, which are applicable irrespective of the type of barrier that ultimately will be constructed. This summary applies to full scale construction and operation of an underground barrier system at the Hanford Site SST Farms. The following issues have been prioritized based on the length of time required to obtain the required permit or approval. Additional details are contained in Appendix A and the notes that follow Appendix A.

\subsection{NATIONAL ENVIRONMENTAL POLICY ACT DOCUMENTATION}

A meeting should be scheduled with the RL NEPA Compliance Officer as soon as sufficient information is available to provide a description of the proposed action (e.g., construction of an underground barrier system). By including $R L$ as early as possible, the preparation and approval process may be expedited. It is anticipated that an ADM/EA will be the recommended level of NEPA documentation required for hot demonstration of an underground barrier system. It is expected that the outcome of the EA will be a FONSI. The approximate time required for completion of the NEPA process for hot demonstration is approximately 6 to 14 months, depending on the scope of the proposed action. NEPA documentation for full scale construction and operation will be addressed via the TWRS-EIS. A ROD for the TWRS-EIS is expected to issued by the middle of 1996.

\subsection{AIR EMISSION PERMITS AND NOTIFICATIONS}

It is expected that an application for prior approval of construction will be required in accordance with 40 CFR 61, NESHAPs. It is also anticipated that a notice of construction (NOC) will be required in accordance with WAC 246-247, "Radiation Protection-Air Emissions" and for WAC 173-460, "Controls for New Sources of Toxic Air Pollutants." A T-BACT analysis must also accompany the NOC that will be required in accordance with WAC 173-460. The importance of involving the regulatory agencies as early as possible in the design process cannot be overstated. The other item of key importance that will expedite the approval process is to provide accurate and complete applications with the first transmittal of information. The approximate time for obtaining each of the above approvals will range from 12 to 16 months.

\subsection{MISCELLANEOUS PERMITS AND APPROVALS}

A cultural resources review will be required in accordance with 36 CFR 800 . This review must be completed before submittal of the required NEPA documentation to RL for approval. 
Because this project is located in a previously disturbed area (e.g., tank farms), no problems are anticipated in completing the review. This review will take approximately 3 months to complete.

An endangered species assessment will be required in accordance with 50 CFR 402.6. This review must also be completed before submittal of the required NEPA documentation to RL for approval. No problems are anticipated in completing this assessment for the same reason as stated above under cultural resources review. This assessment will take approximately 3 to 6 months to complete.

An Excavation Permit is required before initiating any potential surface disturbing activities. NEPA documentation, as well as the Cultural Resources Review and the Endangered Species Assessment, must be completed for the proposed activity before the permit is issued. An excavation permit takes approximately one week to obtain.

Some preoperational monitoring may be required in accordance with DOE Order 5400.1. To determine if this is necessary, contact Environmental Engineering Studies department of WHC. It is possible that monitoring information currently in place may be sufficient. Radiation Protection Standards and monitoring requirements should be discussed in parallel with preoperational monitoring requirements. Preoperational Monitoring should be initiated at least 1 year ahead of operation. Some monitoring may also be required during construction.

\subsection{STATE ENVIRONMENTAL POLICY ACT}

For hot demonstration of an underground barrier system, a SEPA checklist will be required for any permit application or request for approval from Ecology. The SEPA checklist is prepared by the NEPA documentation function and accompanies the permit application or request for approval. It is expected that the checklist will accompany the application for approval to construct in accordance with WAC 173-460. Coordination between the Air and Water Permits Function and the NEPA Function will be important in assuring that the checklist is completed in time to be submitted with this application. The approximate time required for preparation and internal review of the SEPA checklist is 2 months. For full scale construction and operation of an underground barrier, the TWRS-EIS will satisfy the SEPA requirements because Ecology and DOE are cooperative lead agencies for the TWRS-EIS.

\subsection{WASTEWATER DISCHARGES}

It is likely that wastewater produced in conjunction with construction and operation of an underground barrier system will have to be managed as dangerous waste because of the presence of listed waste constituents classified as F001 through F005 dangerous waste. Refer to Section 2.5 of the regulatory analysis for a discussion of alternatives available for 
management of wastewater discharges. Wastewater designated as a listed dangerous waste may not be discharged to the ground unless a delisting petition for such waste has been approved by the EPA and such wastewater is discharged in accordance with a WAC 173-216 permit:

\subsection{DANGEROUS WASTE MANAGEMENT}

Installation of an underground barrier system at the Hanford Site SST Farms will not require a Part A permit application revision. The reason for this is that installation of such barrier will not involve the treatment, storage, or disposal of dangerous waste. However, if secondary waste is generated as a result of construction or operation of the barrier system, then that waste must be managed in a unit that is operating under interim or final status. The level of permit development or modification will be contingent on how such waste is managed and the extent to which additional treatment or storage capacity is required. Section 2.3 should be referred to for a discussion of expanding an existing unit under interim status. Section 2.5 should be referred to for a discussion of the various permitting issues associated with management of secondary waste. 
WHC-SD-EN-RD-010, REV. 0

This page intentionally left blank. 


\subsection{REFERENCES}

\subsection{DOCUMENTS}

Duffy, L. P., 1991, Authorization to Transfer Waste With Possibility of Affecting Tanks with Safety Issues at the Hanford Site, (memo dated September 25), U. S. Department of Energy, Washington, D. C.

Ecology and DOE, 1992, "In the matter of the compliance by United States Department of Energy with Chapter 70.105 and $90.48 \mathrm{RCW}$ and the Rules and Regulations of the Department of Ecology," Consent Order DE 91NM-177 (for the permitting of liquid effluent discharges under Washington Administrative Code 173-216), Washington State Department of Ecology, Olympia, Washington.

Ecology, EPA, and DOE, 1992, Hanford Federal Facility Agreement and Consent Order, 2 vols., as amended, Washington State Department of Ecology, U.S. Environmental Protection Agency, and U.S. Department of Energy, Olympia, Washington.

NIOSH, 1991, Registry of Toxic Effects of Chemical Substances, National Institute for Occupational Safety and Health, U.S. Department of Health and Human Services, Washington, D.C.

\subsection{CODE OF FEDERAL REGULATIONS AND FEDERAL REGISTER}

10 CFR 1201, "National Environmental Policy Act; Implementing Procedures and Guidelines Revocation; Final Rule and Notice," Code of Federal Regulations, as amended.

40 CFR 61, "National Emission Standards for Hazardous Air Pollutants," Code of Federal Regulations, as amended.

40 CFR 261, "Identification and Listing of Hazardous Waste," Code of Federal Regulations, as amended.

40 CFR 265, "Interim Status Standards for Owners and Operators of Hazardous Waste Treatment, Storage, and Disposal Facilities," Code of Federal Regulations, as amended.

40 CFR 270, "EPA Administered Permit Programs: The Hazardous Waste Permit Program," Code of Federal Regulations, as amended.

40 CFR 1500-1508, "Regulations for Implementing the Procedural Provisions of the National Environmental Policy Act," Code of Federal Regulations, as amended. 
45 FR 46115, 1980, "Double-Shell Tanks for Defense High-Level Radioactive Waste

Storage, Hanford Site, Richland, Washington Record of Decision," Federal Register.

52 FR 25766, 1987, "Land Disposal Restrictions for Certain California List Hazardous

Wastes and Modifications to the Framework," Federal Register.

51 FR 25422, 1986, "Hazardous Waste Management System; Standards for Hazardous Waste Storage and Treatment, Tank Systems," Federal Register.

\subsection{FEDERAL AND STATE ACTS}

Clean Air Act, 1955, as amended, 42 USC 7401 et seq.

"Safety Measures for Waste Tanks at Hanford Nuclear Reservation," Section 3137 of National Defense Authorization Act for Fiscal Year 1991, Public Law 101-510, November 5, 1990.

National Environmental Policy Act of 1969, 42 USC 4321 et seq.

State Environmental Policy Act of 1971, Revised Code of Washington 43.21c, Olympia, Washington. (Last revised in 1993.)

Resource Conservation and Recovery Act of 1976, 42 USC 6901 et seq.

Hazardous and Solid Waste Amendments of 1984, 42 USC 6912(a), 6921, 6922, 6924, 6925, 6926, 6930, 6935, 6937, 6939, 6991, and 6993.

\subsection{WASHINGTON ADMINISTRATIVE CODE}

WAC 173-303, "Dangerous Waste Regulations," Washington Administrative Code, as amended.

WAC 173-216, "State Waste Discharge Permit Program," Washington Administrative Code, as amended.

WAC 173-460, "Controls for New Sources of Toxic Air Pollutants," Washington Administrative Code, as amended.

WAC 197-11, "SEPA Rules," Washington Administrative Code, as amended.

WAC 246-247, "Radiation Protection - Air Emissions," Washington Administrative Code, as amended.

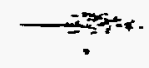


WHC-SD-EN-RD-010, REV. 0

WAC 173-340, "Model Toxics Control Act--Cleanup," Washington Administrative Code, as amended. 
WHC-SD-EN-RD-010, REV. 0

This page intentionally left blank.

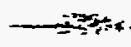


WHC-SD-EN-RD-010, REV . 0

\section{APPENDIX \\ REGULATORY REQUIREMENTS}

App-1 
WHC-SD-EN-RD-010, REV. 0

This page intentionally left blank. 
The following matrix identifies environmental permits, approvals, and/or requirements potentially applicable to full scale construction and operation of an underground barrier system at the Hanford Site SST Farms. The requirements identified in this matrix must be addressed, irrespective of the type of barrier that ultimately will be selected for construction. The applicability column specifies whether or not a given requirement will impact full scale construction and operation of an underground barrier system. A requirement identified with a "Yes" or "To Be Determined" in the last column is further clarified by the associated note and supporting text at the end of this matrix. A requirement identified with a "No" in the last column indicates that the requirement is not applicable. The appropriate organization within the Westinghouse Hanford Company that may be contacted for additional information is also identified.

\section{POTENTIAL ENVIRONMENTAL REGULATIONS FOR CONSTRUCTION AND OPERATION OF AN UNDERGROUND BARRIER SYSTEM}

\begin{tabular}{|c|c|c|c|c|c|}
\hline $\begin{array}{l}\text { Enyironmental } \\
\text { Contannont } \\
\text { Media } \% \text { or } \% \text { \% }\end{array}$ & pernit a pproval & $\frac{1}{1 \%} / \%$ Regulaton & Wegulatory & (4) Restriction. & Applicable \\
\hline NEPA & $\begin{array}{l}\text { NEPA } \\
\text { Documentation }\end{array}$ & 10 CFR 1021 & DOE & $\begin{array}{l}\text { Title II Design } \\
\text { (Projects), } \\
\text { Procurement }\end{array}$ & $\begin{array}{c}\mathbf{Y} \\
\text { See Note 1 }\end{array}$ \\
\hline SEPA & $\begin{array}{l}\text { SEPA } \\
\text { Documentation }\end{array}$ & WAC $197-11$ & State Agency & $\begin{array}{l}\text { License, } \\
\text { Permit }\end{array}$ & $\begin{array}{c}\mathrm{Y} \\
\text { See Note } 2\end{array}$ \\
\hline $\begin{array}{l}\text { Comprehensive } \\
\text { Environmental, } \\
\text { Response, } \\
\text { Compensation, } \\
\text { and Liability Act } \\
\text { of } 1980 \\
\text { (CERCLA) }\end{array}$ & $\mathrm{ARAR}^{2}$ & 40 CFR $300-400$ & EPA & Construction & $\mathbf{N}$ \\
\hline \multirow[t]{2}{*}{ Air Emissions } & NESHAP & $\begin{array}{l}40 \text { CFR } 61 \\
\text { Subpart } H\end{array}$ & EPA & Construction & $\begin{array}{c}\mathrm{Y} \\
\text { See Note } 3\end{array}$ \\
\hline & RAEP $^{2}$ & WAC 246-247 & $\mathrm{DOH}$ & $\begin{array}{l}\text { Construction } \\
\text { Operation }\end{array}$ & $\begin{array}{c}\mathrm{Y} \\
\text { See Note } 4\end{array}$ \\
\hline
\end{tabular}

${ }^{1}$ Applicable or Relevant and Appropriate Requirements (ARAR).

${ }^{2}$ Radioactive Air Emissions Program (RAEP). 
WHC-SD-EN-RD-010, REV. 0

POTENTIAL ENVIRONMENTAL REGULATIONS FOR CONSTRUCTION AND OPERATION OF AN UNDERGROUND BARRIER SYSTEM

\begin{tabular}{|c|c|c|c|c|c|}
\hline 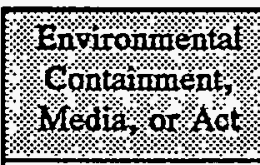 & Perrnit Approval & (4) & Regulatory? & Rे & 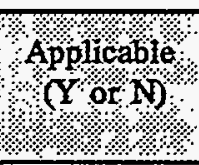 \\
\hline & NOC & $\begin{array}{l}\text { WAC } 173-400 \\
\text { WAC } 173-460 \\
\text { BFCCAA } \\
\text { General } \\
\text { Regulation } 1\end{array}$ & $\begin{array}{l}\text { Ecology } \\
\text { BFCCAA }^{3}\end{array}$ & Construction & $\begin{array}{c}\mathrm{Y} \\
\text { See Note } \\
5\end{array}$ \\
\hline & $\begin{array}{l}\text { Air Operating } \\
\text { Permit }\end{array}$ & WAC $173-401$ & Ecology & Operation & $\begin{array}{c}\mathrm{Y} \\
\text { See Note } \\
6\end{array}$ \\
\hline & $\overline{\mathrm{PSD}^{4}}$ & WAC $173-400$ & $\begin{array}{l}\text { Ecology } \\
\text { BFCCAA }\end{array}$ & Construction & $\overline{\mathbf{N}}$ \\
\hline Asbestos & Notice of Intent & $\begin{array}{l}\text { BFCCAA } \\
\text { General } \\
\text { Regulation } 1 \text {, } \\
\text { Article } 8 \text { and } \\
40 \text { CFR } 61 \text {, } \\
\text { Subpart M }\end{array}$ & BFCCAA & \begin{tabular}{|l} 
Before \\
Working \\
with \\
Asbestos
\end{tabular} & $\bar{N}$ \\
\hline Fire & Fire permit & WAC $173-425$ & $\begin{array}{l}\text { Hanford } \\
\text { Fire } \\
\text { Department }\end{array}$ & $\begin{array}{l}\text { Open } \\
\text { Burning }\end{array}$ & $\overline{\mathrm{N}}$ \\
\hline \begin{tabular}{|l|} 
Soil Column \\
Waste Water \\
Disposal
\end{tabular} & SWDP $^{5}$ & WAC $173-216$ & Ecology & Operation & $\begin{array}{c}\text { TBD } \\
\text { See Note } \\
7\end{array}$ \\
\hline
\end{tabular}

${ }^{3}$ Benton Franklin Counties Clean Air Authority (BFCCA).

${ }^{4}$ Prevention of Significant Deterioration (PSD).

${ }^{5}$ State Waste Discharge Permit (SWDP). 


\section{POTENTIAL ENVIRONMENTAL REGULATIONS FOR CONSTRUCTION AND OPERATION OF AN UNDERGROUND BARRIER SYSTEM}

\begin{tabular}{|c|c|c|c|c|c|}
\hline 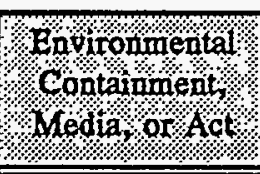 & 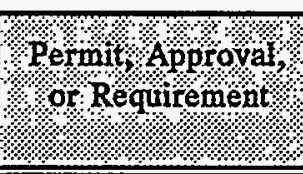 & 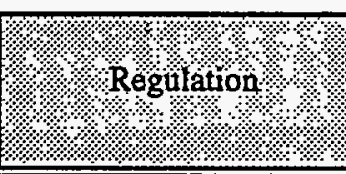 & 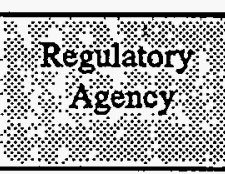 & (2. Restriction & Applicablo \\
\hline & $\begin{array}{l}\text { Approval of } \\
\text { Engineering } \\
\text { Reports, Plans } \\
\text { \& Specification } \\
\text { and O\&M } \\
\text { Manual }\end{array}$ & WAC 173-240 & Ecology & Construction & $\begin{array}{c}\text { TBD } \\
\text { See Note } \\
8\end{array}$ \\
\hline & $\begin{array}{l}\text { UIC' Permit/ } \\
\text { Registration }\end{array}$ & WAC $173-218$ & Ecology & Operation & $\mathbf{N}$ \\
\hline \multirow[t]{5}{*}{$\begin{array}{l}\text { Domestic } \\
\text { Waste Water } \\
\text { Disposal }\end{array}$} & $\begin{array}{l}\text { Septic Systems } \\
<14,500 \text { gpd } \\
\text { Capacity } \\
\text { Design } \\
\text { Approval }\end{array}$ & WAC 246-272 & $\mathrm{DOH}$ & Construction & $\mathrm{N}$ \\
\hline & $\begin{array}{l}\text { Septic Systems } \\
>14,500 \text { gpd } \\
\text { Capacity } \\
\text { Design } \\
\text { Approval }\end{array}$ & WAC $173-216$ & Ecology & Construction & $\mathbf{N}$ \\
\hline & $\begin{array}{l}\text { Pretreatment } \\
\text { Permit }\end{array}$ & $\begin{array}{l}40 \text { CFR } 403 \text {, City } \\
\text { Ordinance }\end{array}$ & $\begin{array}{l}\text { City of } \\
\text { Richland }\end{array}$ & $\begin{array}{l}\text { Discharge to } \\
\text { City Sewage } \\
\text { Facility }\end{array}$ & $\mathrm{N}$ \\
\hline & $\begin{array}{l}\text { Operator } \\
\text { Certification }\end{array}$ & WAC $173-230$ & Ecology & Operation & $\mathbf{N}$ \\
\hline & $\begin{array}{l}\text { Discharge } \\
\text { Standards }\end{array}$ & WAC $173-221$ & Ecology & Discharge & $\mathbf{N}$ \\
\hline $\begin{array}{l}\text { Surface } \\
\text { Waste Water } \\
\text { Disposal }\end{array}$ & NPDES Permit & 40 CFR 122 & EPA & Operation & $\mathbf{N}$ \\
\hline
\end{tabular}

${ }^{6}$ Operations and Maintenance (O\&M).

${ }^{7}$ Underground Injection Control (UIC). 
POTENTIAL ENVIRONMENTAL REGULATIONS FOR CONSTRUCTION AND OPERATION OF AN UNDERGROUND BARRIER SYSTEM

\begin{tabular}{|c|c|c|c|c|c|}
\hline 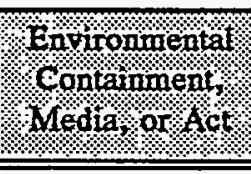 & Prormit, Approval & (1. & Regulatory $^{\text {Agency }}$ & 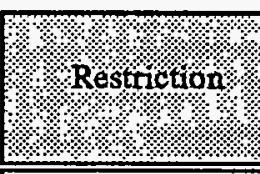 & Applicable) \\
\hline & $\begin{array}{l}\text { Storm Water } \\
\text { Discharge } \\
\text { Under General } \\
\text { Permit }\end{array}$ & 57 FR No. 175 & EPA & \begin{tabular}{|l} 
River \\
Construction
\end{tabular} & $\mathbf{N}$ \\
\hline & $\begin{array}{l}\text { Dredge \& Fill } \\
\text { Permit }\end{array}$ & 33 CFR 320,323 & USACE $^{8}$ & \begin{tabular}{|l} 
River \\
Construction
\end{tabular} & $\bar{N}$ \\
\hline & $\begin{array}{l}\text { Section } 10 \\
\text { Permit }\end{array}$ & 33 CFR 320,322 & USACE & \begin{tabular}{|l} 
River \\
Construction
\end{tabular} & $\mathbf{N}$ \\
\hline & $\begin{array}{l}\text { Nationwide } \\
\text { Permits }\end{array}$ & 33 CFR 330 & USACE & $\begin{array}{l}\text { River } \\
\text { Construction }\end{array}$ & $\overline{\mathbf{N}}$ \\
\hline & $\begin{array}{l}\text { Hydraulic } \\
\text { Projects Permit }\end{array}$ & WAC $220-110$ & $\begin{array}{l}\text { WA Dept. } \\
\text { of } \\
\text { Fisheries }\end{array}$ & \begin{tabular}{|l} 
River \\
Construction
\end{tabular} & $\mathbf{N}$ \\
\hline & $\begin{array}{l}\text { Shoreline } \\
\text { Development } \\
\text { Permit }\end{array}$ & WAC $173-14-20$ & $\begin{array}{l}\text { Benton } \\
\text { County }\end{array}$ & $\begin{array}{l}\text { River/Island } \\
\text { Construction }\end{array}$ & $\mathbf{N}$ \\
\hline & $\begin{array}{l}\text { Aquatic Lands } \\
\text { Lease }\end{array}$ & WAC $332-30$ & $\begin{array}{l}\text { WA Dept. } \\
\text { of Natural } \\
\text { Resources }\end{array}$ & Construction & $\mathbf{N}$ \\
\hline & $\begin{array}{l}\text { Hanford Reach } \\
\text { Study Act } \\
\text { Notification }\end{array}$ & PL 100-605 & $\begin{array}{l}\text { U.S. Parks } \\
\text { Service }\end{array}$ & $\begin{array}{l}\text { Construction } \\
\text { Within } 1 / 4 \\
\text { Mile of the } \\
\text { River }\end{array}$ & $\mathbf{N}$ \\
\hline & $\begin{array}{l}\text { Water Quality } \\
\text { Modification } \\
\text { Permit }\end{array}$ & WAC 173-201 & Ecology & $\begin{array}{l}\text { River } \\
\text { Construction }\end{array}$ & $\overline{\mathbf{N}}$ \\
\hline & $\begin{array}{l}\text { Certification of } \\
\text { NPDES Permit }\end{array}$ & 40 CFR 121 & Ecology & Operation & $\mathbf{N}$ \\
\hline
\end{tabular}

${ }^{8}$ U.S. Army Corps of Engineers (USACE). 


\section{POTENTIAL ENVIRONMENTAL REGULATIONS FOR CONSTRUCTION AND OPERATION OF AN UNDERGROUND BARRIER SYSTEM}

\begin{tabular}{|c|c|c|c|c|c|}
\hline $\begin{array}{l}\text { Environmental } \\
\text { Continment } \\
\text { Medir or Act? }\end{array}$ & Permit Approval; & (1. & Regulatory & (2) & Applicable \\
\hline & $\begin{array}{l}\text { Categorical } \\
\text { Standards }\end{array}$ & 40 CFR 405 - 471 & EPA & Operation & $\mathbf{N}$ \\
\hline \multirow[t]{3}{*}{$\begin{array}{l}\text { Drinking } \\
\text { Water Supply }\end{array}$} & $\begin{array}{l}\text { Approval of } \\
\text { Engineering } \\
\text { Reports, Plans } \\
\text { and } \\
\text { Specifications }\end{array}$ & WAC $246-290$ & $\mathrm{DOH}$ & Construction & $\bar{N}$ \\
\hline & $\begin{array}{l}\text { System } \\
\text { Identification } \\
\text { Number }\end{array}$ & WAC $246-290$ & $\mathrm{DOH}$ & Operation & $\mathbf{N}$ \\
\hline & $\begin{array}{l}\text { Operator } \\
\text { Certification }\end{array}$ & WAC 246-292 & $\mathrm{DOH}$ & Operation & $\mathbf{N}$ \\
\hline Solid Waste & $\begin{array}{l}\text { Solid Waste } \\
\text { Handling } \\
\text { Facility Permit }\end{array}$ & WAC $173-304$ & $\mathrm{BFHD}^{9}$ & Construction & $\mathbf{N}$ \\
\hline $\begin{array}{l}\text { Dangerous } \\
\text { Waste }\end{array}$ & $\begin{array}{l}\text { Dangerous } \\
\text { Waste Permit } \\
\text { (RCRA - A/B) }\end{array}$ & $\begin{array}{l}\text { WAC 173-303 \& } \\
40 \text { CFR 264, 265, } \\
270\end{array}$ & Ecology & $\begin{array}{l}\text { Construction } \\
\text { of New } \\
\text { Facilities or } \\
\text { Expansion of } \\
\text { Existing } \\
\text { Facilities }\end{array}$ & $\begin{array}{c}\text { Y } \\
\text { See Note } \\
9\end{array}$ \\
\hline $\begin{array}{l}\text { Underground } \\
\text { Storage } \\
\text { Tanks }\end{array}$ & Tank Permit & WAC $173-360$ & Ecology & Operation & $\mathbf{N}$ \\
\hline All Media & $\begin{array}{l}\text { Floodplain } \\
\text { Wetland } \\
\text { Assessment }\end{array}$ & 10 CFR 1022 & DOE & $\begin{array}{l}\text { Any Surface } \\
\text { Disturbance }\end{array}$ & $\mathbf{N}$ \\
\hline
\end{tabular}

${ }^{9}$ Benton Franklin Health Department (BFHD). 
WHC-SD-EN-RD-010, REV. 0

\section{POTENTIAL ENVIRONMENTAL REGULATIONS FOR CONSTRUCTION AND OPERATION OF AN UNDERGROUND BARRIER SYSTEM}

\begin{tabular}{|c|c|c|c|c|c|}
\hline 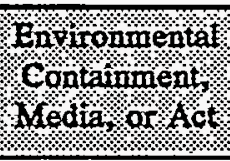 & $\begin{array}{l}\text { Peruit , Approval } \\
\text { oo Requirement }\end{array}$ & (1. & $\begin{array}{l}\text { Regulatong } \\
\text { Ragency } \\
\text { Pol }\end{array}$ & (1. Restriction & Applicabie \\
\hline & $\begin{array}{l}\text { Cultural } \\
\text { Resource } \\
\text { Review } \\
\text { Clearance }\end{array}$ & 36 CFR 800 & DOE & $\begin{array}{l}\text { Surface } \\
\text { Disturbing } \\
\text { Activities \& } \\
\text { Modification } \\
\text { of Buildings } \\
\text { Eligible for } \\
\text { Listing on } \\
\text { Historical } \\
\text { Register }\end{array}$ & $\begin{array}{c}\mathrm{Y} \\
\text { See Note } \\
10\end{array}$ \\
\hline & $\begin{array}{l}\text { Excavation } \\
\text { Permit }\end{array}$ & 36 CFR 800 & DOE & $\begin{array}{l}\text { Excavation } \\
\text { Project }\end{array}$ & $\begin{array}{c}\mathrm{Y} \\
\text { See Note } \\
11\end{array}$ \\
\hline & $\begin{array}{l}\text { Endangered } \\
\text { Species } \\
\text { Approval }\end{array}$ & 50 CFR 402.6 & $\begin{array}{l}\text { Fish and } \\
\text { Wildlife } \\
\text { Service }\end{array}$ & $\begin{array}{l}\text { Construction } \\
\text { Habitat } \\
\text { Modification }\end{array}$ & $\begin{array}{c}\mathrm{Y} \\
\text { See Note } \\
12\end{array}$ \\
\hline & $\begin{array}{l}\text { Preoperation } \\
\text { Monitoring of } \\
\text { Facilities, } \\
\text { Sites, \& } \\
\text { Operations }\end{array}$ & $\begin{array}{l}\text { DOE Order } \\
5400.1\end{array}$ & DOE & Operation & $\begin{array}{c}\mathrm{Y} \\
\text { See Note } \\
13\end{array}$ \\
\hline & $\begin{array}{l}\text { Radiation } \\
\text { Protection } \\
\text { Standards }\end{array}$ & $\begin{array}{l}\text { DOE Order } \\
5400.5\end{array}$ & $\mathrm{DOE}$ & Construction & $\begin{array}{c}\text { Y } \\
\text { See Note } \\
14\end{array}$ \\
\hline
\end{tabular}


TABLE 1: NOTES

NOTE 1. 10 CFR 1021 defines "Compliance with the National Environmental Policy Act." NEPA establishes the national environmental policy and goals, and provides a method for accomplishing those goals. The Council on Environmental Quality is charged with monitoring progress toward achieving those goals. The act requires the preparation of a statement that considers environmental impacts, alternatives, and resource commitments for any major federal action that significantly affects the quality of the human environment. All federal agencies are required to develop methods and procedures to ensure that environmental considerations are factored into all decision-making processes.

A NEPA review is required for all proposed actions at the Hanford Site. Documentation of the completed NEPA review process could include an EIS, an EA, or a CX. The EIS is required for proposed actions significantly affecting the quality of the human environment. In cases where it is uncertain whether a EIS is required, an EA is prepared. A CX is issued by DOE if the proposed action clearly would have no significant impact on the quality of the human environment. However, any action that is determined categorically excluded still requires documentation. It is important to note that all cultural resource surveys and ecological surveys or reviews must be completed before NEPA documentation is submitted to RL.

The NEPA Documentation Group expects that an ADM/EA will be the level of NEPA documentation required for hot demonstration of an underground barrier system. The ADM is prepared to assist the DOE in the final determination as to the level of NEPA documentation required. Recent efforts to streamline the regulatory review process has resulted in a transition of NEPA decision making authority from DOE-HQ to RL. This transition of authority is expected to expedite the DOE review and approval process. Preparation and approval of an EA traditionally has taken anywhere from six to fourteen months depending on the scope of the proposed action. A meeting should be scheduled with the RL NEPA Compliance Officer to expedite the documentation preparation and review process. This meeting can be arranged through the WHC NEPA documentation function.

For full scale construction and operation of an underground barrier system, the environmental impacts will be discussed in the Tank Waste Remediation System - Environmental Impact Statement (TWRS-EIS). Because hydraulic sluicing may cause tank waste to be released from the SSTs and result in an increase in soil contamination, construction of an underground barrier system has been determined to be a connected action since environmental impacts result from the proposed action (e.g., tank waste retrieval).

Additional information on this matter may be obtained by contacting the NEPA Documentation Group.

NOTE 2. WAC 197-11 defines "SEPA Rules." SEPA ensures that environmental impacts are considered by state and local governmental officials when making permitting decisions. This legislation requires an evaluation of environmental impacts associated with a given project before Ecology can make a decision on permit approval.

SEPA requires evaluation of environmental impacts associated with a project before approval (license or State permit). A SEPA checklist is completed if required by the State or local agency. The agency will determine if a State EIS is required or will issue a determination of non-significance.

For hot demonstration of a underground barrier system, a SEPA checklist will be required for any permit application or request for approval from Ecology. The SEPA checklist is prepared by the NEPA documentation function and accompanies the permit application or request for approval. For full scale construction and operation, the TWRS-EIS will satisfy the SEPA requirements because Ecology and DOE are cooperative lead agencies for the TWRS-EIS.

Additional information on this matter may be obtained by contacting the NEPA Documentation Group. 
NOTE 3. 40 CFR 61, "National Emission Standards for Hazardous Air Pollutants," establishes standards for atmospheric emissions of hazardous air pollutants and radionuclides. Any new stationary source of radionuclide emissions or modification of an existing source that will result in an increase in emissions of radioactive pollutants to the atmosphere is subject to a pre-construction review and approval by the EPA.

Any new stationary source or modification of a stationary source of radionuclide emissions is subject to a preconstruction review and approval by the EPA, Region 10. The adjective "stationary" is meant to be applied to the source while it is operational.

The underground barrier system will require prior approval for any construction or modification activities. The application for approval of construction must include "technical information describing the proposed nature, size, design, operating design capacity, and method of operation of the source, including a description of any equipment to be used for control of emissions." Such technical information shall include calculations of emission estimates in sufficient detail to permit assessment of the validity of the calculations. The Air and Water Permits function is responsible for preparation of the request for approval to construct that is submitted to the EPA, Region 10.

NOTE 4. WAC 246-247, "Radiation Protection - Air Emissions," establishes procedures for monitoring, controlling, and reporting airborne radionuclide emissions from specified sources. Use of best available radionuclide control technology is required for new sources and modifications to existing sources that will significantly change the potential radionuclide emissions or dose equivalent to the public.

All new and modified sources of radionuclide emissions are subject to a preconstruction review and approval by the DOH. The definition of a modification in WAC 246-247-030(17) is, "addition to, enlargement, replacement, or alteration of any process or source which will significantly change potential emissions." The definition of "potential to emit" is defined as the maximum rate of release of radionuclides from an emission unit, assuming no emission control equipment is present but operations are otherwise normal. The determination of "potential to emit" is calculated using one of the following methods:

- Multiply the annual possession quantity of each radionuclide by the release fraction for that radionuclide depending on its physical state (40 CFR 61, Appendix D), to determine the level of documentation required to obtain regulatory approval to construct.

- Perform a back-calculation using measured emission rates and in situ measurements of the control equipment efficiencies, as approved by the EPA and DOH; or

- Use an alternative method approved by EPA and the DOH.

If the calculated committed effective dose equivalent (CEDE) to the maximally exposed individual (MED), caused by the emissions, is calculated to be more than 0.1 millirem per year, a NOC must be submitted to the $\mathrm{DOH}$ for approval. Also, addition to, enlargement, modification, replacement, or alteration of emission control equipment that will significantly change potential emission or dose to the public will require the use of best available radionuclide control technology (BARCT) for emission control pursuant to WAC 246-247-070(3). If the CEDE to the MEI, caused by the emissions, is less than 0.1 millirem per year, a less detailed notification must be submitted to the DOH for approval before construction.

For the underground barrier system, registration of a new source of radionuclide emissions will be required in accordance with WAC 246-247-050. Once the registration is determined to meet both Ecology and DOH regulations, a permit will be issued authorizing the source in accordance with WAC 246-247-060. A NOC will be required before commencement of construction, in accordance with WAC 246-247-070. The construction, installation or establishment of a new regulated source of emissions shall use the BARCT. 
NOTE 5. WAC 173-460, "Controls for New Sources of Toxic Air Pollutants, "specifies that emissions of toxic air pollutants require the use of best available control technology and a determination of whether the source is above or below the corresponding acceptable source impact level.

The following sequence of questions and regulatory requirements should be evaluated during an analysis to determine the applicability of WAC 173-460:

1. Will the source emit TAPs other than non-process fugitive emissions in a significant quantity?

2. Does the source fall into one of the source categories specified by WAC 173-460?

3. Is the source exempt?

4. Is this a "new source" of TAPs?

5. Sources for which there are increases in TAPs or TAPs not previously emitted require the use of T-BACT.

6. Sources for which the rate of emissions associated with a given project will decrease or stay the require the use of T-RACT.

For the underground barrier system, a NOC must be prepared for submittal to Ecology. Emissions of TAPs must be quantified in such detail as to determine compliance with the rule's provisions. These regulations also specify the level of control technology that must be implemented. The underground barrier system will require T-BACT. The NOC, including the T-BACT must be approved before commencement of construction of the new source.

NOTE 6. WAC 173-401, "Air Operating Permit," was promulgated on October 4, 1993 and requires all major sources to have an air operating permit for their facilities. These permits will address air emissions from all units that emit any of the criteria pollutants listed in the Federal CAA (e.g., NOx or SOx) or any of the 189 hazardous air pollutants listed in the Federal CAA.

The permit will establish emission limits and operational restrictions for the Hanford Site and all operational units located on the site. If a unit becomes operational after the permit is issued by the state, an application to modify the permit will be required. This application for modification shall be prepared in accordance with WAC 173-401-725.

An assumption has been made that the underground barrier system will be operating after the Hanford Site Air Operating Permit has been issued. If this assumption is correct, information contained in other air permit applications required for construction and operation of the underground barrier system will be used to prepare an application for modification to the Hanford Site Air Operating Permit in accordance with WAC 173-401-725.

NOTE 7. WAC 173-216, "State Waste Discharge Permit Program," governs discharge of waste materials into ground and surface waters of the state and into municipal sewer systems. Any waste water discharge to the soil 
column that may adversely impact the groundwater is subject to permitting requirements. Any project that will generate a waste water discharge intended for disposal to the soil column will require an evaluation to determine the applicability of WAC 173-216.

A State Waste Discharge Permit (SWDP) is required before discharging waste materials from industrial, commercial, and municipal operations into ground and surface waters of the state and into municipal sewerage systems. A SWDP is not required for discharges of pollutants into navigable waters that are covered by an NPDES permit program or injection of fluids through wells, which is regulated by the underground injection control program.

Existing wastewater streams at the Hanford Site will be permitted under WAC 173-216, in accordance with a schedule established in Consent Order Number 91NM-177. Additional wastewater streams that will be discharged to the soil column may require revisions to the Tri-Party Agreement and/or the referenced consent order.

For the underground barrier system, the discharge of wastewater to the ground will only be allowed if such wastewater is not classified as a dangerous waste. As discussed in the accompanying regulatory analysis, the wastewater in question will most likely be classified as a listed dangerous waste because of the presence of listed waste constituents classified as F001 through F005 per WAC 173-303-9904. Listed waste contaminated wastewater may be discharged to the ground provided it is delisted by the EPA and discharged in accordance with a WAC 173-216 permit.

NOTE 8. WAC 173-240, "Submission of Plans and Reports for Construction of Wastewater Facilities," specifies that any project that will generate a waste water discharge intended for disposal to the soil column must obtain a waste water discharge permit. The owner or operator must first submit to Ecology, for approval, all engineering reports, plans and specifications for the project in question. Operation and maintenance manuals must be submitted before completion of construction.

Before construction or modification of those domestic or industrial wastewater facilities requiring Ecology wastewater discharge permits, engineering reports, plans, and specifications for the project must be submitted to and approved by Ecology. Operation and maintenance manuals must be submitted before completion of construction.

If the wastewater to be discharged is determined not to be a dangerous waste, engineering reports, plans, and specifications for the project must be submitted to and approved by Ecology.

NOTE 9. WAC 173-303, "Dangerous Waste Regulations," apply to the generation, transportation, treatment, storage, and disposal of dangerous waste. They establish technical standards and functional requirements for various types of treatment, storage, or disposal units. Their purposes are to designate those solid wastes that are dangerous or extremely hazardous; provide for surveillance and monitoring of dangerous and extremely hazardous wastes; provide the form and rules necessary to establish a system for manifesting, tracking, reporting, monitoring, record keeping, sampling, and labeling dangerous and extremely hazardous wastes; establish the sitting, design, operation, closure, post-closure, financial, and monitoring requirements for dangerous and extremely hazardous waste transfer, treatment, storage, and disposal facilities; establish design, operation, and monitoring requirements for managing the state's extremely hazardous waste disposal facility; establish and administer a program for permitting dangerous and extremely hazardous waste management facilities; and encourage recycling, reuse, reclamation; and recovery to the maximum extent possible.

Any facility used for the treatment, storage or disposal of dangerous waste must obtain the necessary dangerous waste permits. Determination of whether a waste is a regulated dangerous waste must be done in accordance with WAC 173-303-070 designation procedures. Existing Hanford Facility TSD units are receiving permits in 
accordance with schedules and procedures identified in the Tri-Party Agreement. New Hanford Facility TSD units that are not identified in the Tri-Party Agreement will require development of a permitting plan to detail the strategies and schedules to be used for development of the necessary dangerous waste permits. This plan must be developed early in the project development phase. Strategies and schedules to be used for development of the necessary dangerous waste permits for new TSD units will need to be discussed with the appropriate regulatory agencies in order to gain their concurrence.

Section 2.0 of the accompanying regulatory analysis provides a comprehensive discussion of dangerous waste management activities as applied to construction of underground barrier system on the Hanford Site.

Section 1.1 discusses the regulatory status of the SSTs, including closure requirements. Section 2.1 identifies listed waste concerns and potential impacts on the management of contaminated wastewater or soil excavated or generated during construction or operation of a barrier system. Section 2.2 describes barrier requirements. Section $\mathbf{2 . 3}$ describes the requirements and special considerations that may be necessary, depending on the type of barrier system selected. Section 2.4 provides a discussion of the use of regulated barrier materials. Section 2.5 evaluates various alternatives for management of secondary waste (e.g., wastewater). Section 2.6 discusses delisting issues. Section 2.7 identifies land disposal restrictions and considerations applicable to an underground barrier system. Section 2.8 evaluates closure issues.

NOTE 10. 36 CFR 800, "Protection of Historical and Cultural Properties," specifies that a Cultural Resource Review/Clearance shall be performed before initiating any potential surface-disturbing activities onsite or if any modifications are planned for any facility with the potential for inclusion on the National Historical Register.

A cultural resource review shall be performed for the underground barrier system. Because the barrier system will be installed within previously disturbed areas, the process most likely will be limited to providing Pacific Northwest Laboratories with a description of the project. A letter will then be returned allowing commencement of construction.

NOTE 11. 36 CFR 800, "Protection of Historical and Cultural Properties," specifies that an excavation permit is required before initiating any potential surface-disturbing activities onsite. Any excavation associated with the underground barriers will require an excavation permit before initiating any surface-disturbing activities onsite. It is also important to note that completion of Cultural Resource Review and Endangered Species Act requirements must be completed before approval of the excavation permit.

NOTE 12. 50 CFR 402, "Endangered Species Approval," specifies that for any construction project, a biological assessment must be prepared to determine the possible impact of the project on any threatened or endangered species or their habitats.

A site assessment should be made to determine whether any planned activities have the potential to disturb any critical habitat used by threatened and/or endangered species.

A site assessment will be required for the underground barrier system before beginning site activities that could have the potential to disturb critical habitats used by threatened and/or endangered species. It is likely that no special limitations will be placed on construction or operation because of the previously disturbed nature of the area within the Hanford Site Tank Farms.

NOTE 13. DOE Order 5400.1, "General Environmental Protection Program," establishes environmental protection program requirements, authorities, and responsibilities for assuring compliance with applicable 
federal, state, and local environmental protection laws and regulations, Executive Orders, and internal DOE policies. The order more specifically defines environmental protection requirements that generally are established in DOE 5480.1B.

An environmental study shall be conducted before startup of a site, facility, or process which has the potential for significant adverse environmental impact. This study should begin not less than one year and preferably two years before startup to evaluate seasonal changes. This study precedes the conceptual design report and can include data acquired in the site selection process, excavation permit process, and NEPA/SEPA process. The environmental study process is discussed in greater detail in the Environmental Compliance Manual (WHC-CM-7-5) in Sections 5.0, 8.0, and 9.0.

Some preoperational monitoring most likely will be required for the underground barrier. When sufficient scope and design information is available, a meeting should be scheduled with Mr. A. R. Johnson, Environmental Engineering Studies for a determination of the type and amount or preoperational monitoring will be required.

Additional information on this matter may be obtained by contacting Environmental Engineering Studies.

NOTE 14. DOE Order 5400.5, "Radiation Protection of the Public and the Environment," establishes standards and requirements for operations with respect to protection of members of the public and the environment against undue risk from radiation. Policy, with respect to applicability of radiation protection standards, is described. The order sets dose limits for public exposure to radiation from DOE operations, sets limits for releases of radiation to air and water, and requires radiation doses to individuals be maintained ALARA.

The DOE Order 5400.5 establishes standards and requirements that must be followed with respect to protection of members of the public and environment against undue risk from radiation. The general environmental protection program requirements are established in DOE Order 5400.1. This DOE Order requires that all DOE Sites prepare an Environmental Monitoring Plan. The DOE/RL-91-50, "Environmental Monitoring Plan," includes the DOE/EH-0173T, "Environmental Regulatory Guide for Radiological Effluent Monitoring and Environmental Surveillance," which provides specific guidance regarding environmental monitoring activities.

The requirements of this order will be applicable to the underground barrier system. The applicable requirements should be developed in conjunction with the preoperational monitoring requirements discussed above. 